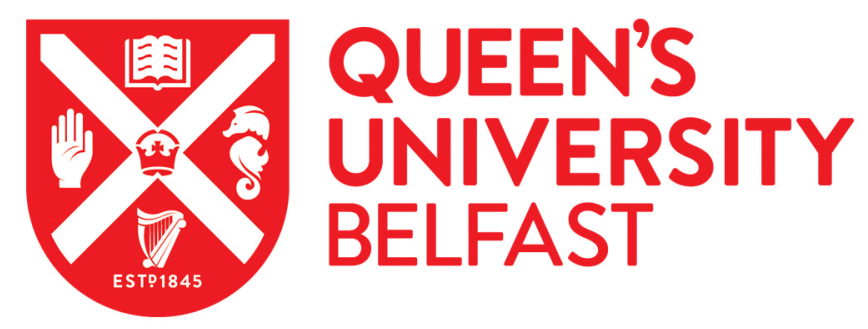

\title{
Moustaches, mantles and saffron shirts: what motivated sumptuary law in medieval English Ireland?
}

Booker, S. (2021). Moustaches, mantles and saffron shirts: what motivated sumptuary law in medieval English Ireland? Speculum, 96(3). https://www.journals.uchicago.edu/doi/pdf/10.1086/714426

\section{Published in:}

Speculum

\section{Document Version:}

Peer reviewed version

Queen's University Belfast - Research Portal:

Link to publication record in Queen's University Belfast Research Portal

\section{Publisher rights}

Copyright 2020 Medieval Academy of America.. This work is made available online in accordance with the publisher's policies. Please refer to any applicable terms of use of the publisher.

\section{General rights}

Copyright for the publications made accessible via the Queen's University Belfast Research Portal is retained by the author(s) and / or other copyright owners and it is a condition of accessing these publications that users recognise and abide by the legal requirements associated with these rights.

Take down policy

The Research Portal is Queen's institutional repository that provides access to Queen's research output. Every effort has been made to ensure that content in the Research Portal does not infringe any person's rights, or applicable UK laws. If you discover content in the Research Portal that you believe breaches copyright or violates any law, please contact openaccess@qub.ac.uk. 
Moustaches, mantles and saffron shirts: what motivated sumptuary law in medieval

\author{
English Ireland?
}

\author{
Sparky Booker \\ Queen's University Belfast \\ s.booker@qub.ac.uk
}

\title{
Introduction
}

The later Middle Ages witnessed an upsurge in laws regulating displays of status, particularly relating to clothing, but also to feasting, weddings, hunting accoutrements and other outward shows of wealth. ${ }^{\text {i }}$ These laws are, generally, known as sumptuary laws. ${ }^{\text {ii }}$ They were enacted with increasing frequency from the late thirteenth century onward by central and municipal administrations in the English colony in Ireland, just as they were across medieval Europe. iii Sumptuary law was versatile and even a single law could be prompted by several different motivations. These motivations were sometimes laid out in explanatory preambles to the legislation that became common in the later fourteenth century, and often cited moral and economic justifications. ${ }^{\text {iv }}$ Economically protectionist sumptuary law, frequently couched in patriotic language, survives from Germany, Scotland, England and the Italian cities. ${ }^{v}$ The central aim of most of these laws, however, was to make each person's status visible through their dress and ensure that their appearance did not misrepresent their place in society. ${ }^{\mathrm{vi}}$ Legislators attempted to impose through clothing and other visual markers an idealized and well-ordered social world that rarely existed in reality. ${ }^{\text {vii }}$ The type of status that authorities wanted to be signaled might be occupational, social, economic, marital, religious or ethnic. ${ }^{\text {viii }}$ Because of this, sumptuary law can tell us a great deal about the social world as governing elites envisioned it and desired it to be; these laws reveal the concerns that drove lawmakers and indicate which 
distinctions they felt were most important to maintain and make visually apparent. Accordingly, sumptuary law has been mined by historians of medieval Europe to shed light on the anxieties and mentalities of lawmakers. ${ }^{\text {ix }}$ This approach has not been fully realized in the historiography of English Ireland, however, and it is all the more valuable since there is relatively little other material like the personal letters and devotional, literary and artistic commissions that provide insight into elite mentalities elsewhere in Europe. ${ }^{x}$ In terms of implementation, the success of enforcement of sumptuary laws varied. ${ }^{\mathrm{xi}}$ Indeed historians disagree about whether these laws were intended to be enforced fully, or whether they were "primarily symbolic", a method of "affirm[ing] values" and even actively shaping the social world by enshrining socio-economic divisions in law. ${ }^{\text {xi }}$ The effectiveness of sumptuary law, however, is not a concern of this study, which instead interrogates the motivations and justifications that prompted and underlay it.

The following pages survey sumptuary laws enacted between 1297, when the colonial parliament in the colony promulgated its first sumptuary law (as far as we know), and 1541. xii The analysis of this material from English Ireland will, it is hoped, contribute to wider debates about the purposes and nature of sumptuary law, while comparison with the wider European corpus of these laws throws into sharper relief the notable characteristics of the laws passed in the colony in Ireland. ${ }^{\text {xiv }}$ As was common across Europe, the laws from the colony were often urban in origin and most numerous in the fifteenth and sixteenth centuries, but, unlike much of the European material, they rarely regulated the dress of women or cited moral motivations for their enactment. ${ }^{\mathrm{xv}}$ What is most striking about the material from Ireland is that much of it was clearly prompted by concerns about ethnic differentiation, while laws driven by the desire to demarcate social and status divisions within colonial society or limit the consumption of luxury items were uncommon.

The attention paid in Ireland's sumptuary laws to visual markers of ethnicity must be understood in the context of the colony's frontier location. The colony's history began with the arrival of English and Welsh allies of the Irish king of Leinster, Diarmait Mac Murchada, in the 
later twelfth century, and the assertion by Henry II of his overlordship of the territories they had conquered during his visit to Ireland in 1170-1. Colonization proceeded rapidly over the following decades, but it stalled and was, in some areas, even reversed in the later thirteenth and fourteenth centuries and the island was never brought fully under the control of the English crown. ${ }^{\text {xi }}$ Thus the colony, with English-style institutions, including its own parliament known as the Irish parliament, an English-style legal system, and close ties to the crown, coexisted with extensive areas under Irish control and a large and shifting swathe of borderland between the two. The borderland was just as much a "contact zone" as it was a locus for ethnic conflict and the colony as a whole was deeply influenced by its Irish neighbors and indeed by the many Irish people who lived within its bounds. ${ }^{\text {xvi }}$ Cultural exchange, intermarriage and social and economic cooperation were widespread. This extensive assimilation alarmed some elements within the governing elite of the colony, and their anxieties shaped the sumptuary law, which sought to encourage English styles and make visible the Englishness of the English of Ireland. ${ }^{\text {xiii }}$

These were the particular conditions of the colony, but it was, of course, very much part of the wider medieval world, albeit on its western edge, and its sumptuary law is assessed here in that broader context. The comparisons made are necessarily qualitative and even impressionistic given the broad chronological and geographical scope of this study. ${ }^{\text {ix }}$ Furthermore, the patchy survival of Irish documentary material makes extensive quantitative analysis impossible. England, with which the colony shared a monarch, institutional models and close social, political, and cultural links, is a sensible first port of call for comparison. ${ }^{\mathrm{xx}}$ Unfortunately, sumptuary law from Wales and the marches does not survive, as this may be an even more fitting comparator for Ireland. The regions shared similar institutions and the same monarch, and the English who settled there contended with similar problems of inter-ethnic hostility and the difficulty of marking out ethnic groups clearly, especially in the aftermath of the Glyndŵr rebellion of the early fifteenth century. ${ }^{\mathrm{xxi}}$ English statutes were in force in Wales, but there are no surviving municipal statutes addressing attire nor were there statutes passed by the English parliament 
specifically for the Welsh situation, even though it is clear that dress was an important ethnic marker there. ${ }^{x x i}$ Scotland, also a close neighbor of the colony and with similarly militarized frontier society, did produce sumptuary law and is a fruitful locus for comparison. ${ }^{\text {xiii }}$ The rise of frontier studies has encouraged comparisons between the colony in medieval Ireland and both the Iberian Peninsula and central Eastern Europe. While further afield and culturally and institutionally very different from the colony, both contended with many of the same issues of ethnic or religious differentiation that marked the Irish situation, and the ways in which rulers and civic bodies there dealt with this differentiation can be instructive. ${ }^{\text {xxiv }}$

Regulations from France, Germany, Italy, the Low Countries and Switzerland will also be considered here. Ireland's ongoing economic and ecclesiastical contacts with the rest of Europe, as well the colony's shared intellectual and institutional Norman/Anglo-Norman heritage, ensured that some of the wider currents within European sumptuary law were evident there. Despite this, laws regarding dress in the colony have not been well-integrated into surveys of sumptuary law, which tend to ignore Ireland entirely or cite it in passing (and in error) as evidence of the way that these laws could be used to suppress the identity and distinctiveness of ethnic groups like the Irish. ${ }^{\mathrm{xxv}}$ Conversely, historians of medieval Ireland have not examined laws regarding appearance as a discreet body of law or looked to European examples to determine how Irish laws fit into the wider framework. This is not unusual in the historiography of sumptuary law as a whole, which has tended to divide itself along modern national lines.

\section{Terminology and the legislative framework}

Sumptuary, strictly speaking, refers to laws that restrained consumption, as many laws regarding appearance did, but the term is applied here in a broader sense. ${ }^{\text {xvi }}$ The definition employed here encompasses any law or ordinance that sought to control visual displays of status or identity, whether through attire, hairstyles, weaponry or through activities like hunting, feasting or the hosting of extravagant weddings and funerals. Importantly, it includes both "negative" 
sumptuary laws, which sought to limit what a given person could spend, and "positive" ones, which aimed to make certain people spend more. This inclusive "visual display" definition is common in studies of sumptuary law and allows for comparison with the existing literature across Europe, although it excludes other equally important methods of signaling identity and status, like language use, which was often subject to regulation in the same statutes that addressed clothing in the English colony in Ireland. ${ }^{\text {xvii }}$

There is an important question to address before surveying sumptuary laws from the colony, and that is whether English laws were automatically in force there. If so, English sumptuary laws should be included in the corpus of Irish material. The nature of Ireland's relationship to English statutory law was complex and contested, and whether the famous claim of 1460 that Ireland was “corporate of itself' had any basis in fact has been an enduring argument in Irish historiography. ${ }^{\text {xxviii }}$ J.A. Otway-Ruthven called the 1460 claim a "mere aberration" and H.G. Richardson and G.O. Sayles argued that English statutes were automatically extended to Ireland, but admitted that the colonial administration challenged this principle in 1380 as well as in $1460 .{ }^{\text {xix }}$ It was also challenged in 1423 and again in 1441, when the eminent jurist and soon to be chief justice of the King's Bench, John Fortescue, opined that "le terre dirlande est severe del roialme dengleterre: the territory of Ireland is separate from the kingdom of England". ${ }^{x x}$ Certainly, English statutes generally had to be proclaimed in Ireland, and Brand asserts that "proper procedure" by the late thirteenth century was for English statutes to be "published" by the Irish parliament in order to put them in force. ${ }^{\text {xxi }}$

A 1320 meeting of the Irish parliament determined that English statutes should be examined by the king's council in Ireland, published by the Irish parliament, and that elements of the statutes "covenables sount pur le poeple e la pees de la terre Dirlande soient illuesques confermetz et tenutz, salves toutr jours les bones custumes et usages de la terre: applicable to the people and the peace of the land of Ireland be from thenceforth confirmed and held, saving always the good customs and usages of the land". xxxii The parliament rolls show that this confirmation and publication process 
had occurred before 1320 but it was the practice routinely thereafter. ${ }^{\text {xxiii }}$ Thus by 1320 the Irish parliament recognized that English statutes might not be applicable in their entirety to Ireland. It noted also that the "customs and usages" of English Ireland might differ from those of England but that these customs should nevertheless be upheld in the colony. By the fifteenth century and up to Poynings law in 1494 there seems to have been considerable uncertainty about whether the Irish parliament must approve - and whether they had the right to decline - English statues before it published them. ${ }^{\text {xxiv }}$ Resistance to the imposition of English statutes without approval was voiced by the chancellor and treasurer of Ireland in 1423, as well as in the 1460 declaration, and uncertainty about the matter was expressed in the Irish parliament in 1467-8. This uncertainty seems to have been most acute in the fifteenth century. ${ }^{\mathrm{xxv}}$ Even after 1494, the survival of the Irish Parliament and occasional assertions of its independence of action and resistance to crown activities ensured that statutes from England were enforced more effectively if they secured the assent of that body. ${ }^{\text {xxvi }}$ A letter from Henry VIII to one of his agents in Ireland in 1537 suggests that he saw the "passing" of legislation in the Irish parliament as necessary to, or at least desirable for, its enforcement in the colony, but his assumption that his legislation would encounter no resistance may suggest that he saw this as mere rubber stamping. ${ }^{\text {xxvii }}$ In any event, whether these proclamations of English statutes signaled the assent of the Irish parliament or were essentially automatic, they usually left some trace in the Irish records.

For example, the Ordinance and the Statute of Labourers, passed in England in the wake of the Black Death, were enrolled in 1349 in two collections of municipal documents - the White Book of Dublin and the Liber Primus Kilkenniensis - and in the records of the Irish parliament in the same year. An additional parliamentary enactment relating to their enforcement was passed two years later. This indicates that both central and municipal authorities in the colony recorded those enactments from England that they intended to enforce. ${ }^{\text {xxviii }}$ We also have record of the Ordinance in Irish chancery letters from 1349. ${ }^{x x x i x}$ Similar evidence regarding English sumptuary 
law does not exist in the Irish administrative sources. Moreover, the preambles of statutes and ordinances often referenced relevant existing laws in order to make clear how they supplemented or modified them, but Irish sumptuary laws do not reference those from England. ${ }^{\mathrm{xl}}$ Accordingly, while English sumptuary statutes may or may not have been, in theory, law in Ireland (and this probably varied over the period examined here), none after English legislation of 1326, which recognized a number of staple towns in Ireland, made a mark in the records of the colony. ${ }^{\text {li }}$ This suggests that they were neither proclaimed nor enforced in Ireland, and can thus be excluded from the corpus of Irish sumptuary law.

\section{The earliest sumptuary laws in the colony}

The earliest known sumptuary law from the colony was passed in 1297. It was an enactment of the Irish parliament prohibiting colonists from wearing a cúlán, which was a hairstyle with long hair in the back and short or shaven hair at the top and around the ears. It was favored by the Irish, perhaps particularly Irish warriors and Irishmen of high status. ${ }^{\text {xli }}$ If it was indeed a highstatus style, this could account for the desire of Englishmen in the colony who had extensive dealings with the Irish to adopt it. The enactment reads:

Anglici eciam quasi degeneres modernis temporibus bybernicalibus se indunt vestimentis et habentes capita semirasa capillos a retro capitis nutriunt et allongant et illos culan vocant bybernicis tam habitu quam facie sese conformantes per quod frequenter accidit anglicos quosdam pro bybernicis reputatos interfici licet anglicorum et bybernicorum occisio diversos modos postulat puniendi et per occisionem buiusmodi inter quamplurimos inimicicie materia generatur et rancoris; affines quoque tam occisoris quam occisi sepe prosternuntur alternatim velud inimici; et eo circa concordatum est et concessum quod omnes anglici in hac terra saltim in capite quod plus visui se presentant mores et tonsuram gerant anglicorum nec amplius presumant avertere comes in colanum quod si fecerint justic[iarius] vicecomes senescallus libertatum domini eciam in quorum dominio anglici buiusmodi reperiantur et eorum senescallus anglicos illos per terras et catalla sua necnon et per arestacionem 
corporis sui et imprisonamentum si necesse fuerit habitum bybernicalem saltim in capite seu capillis relinquere distringant et compellant nec amplius respondeatur anglico capud habendi in forma bybernici transmutatum quam bybernico respondetur si in casu consimili questus esset. in modern times, Englishmen, as if degenerate, wear Irish clothing and having their heads half shaven, grow their hair long at the back of the head and call it a culan, conforming to the Irish in both dress and appearance. As a result, it frequently happens that some Englishmen are killed and taken to be Irishmen, although the killing of Englishmen and of Irishmen requires different modes of punishment: :liii $^{\text {by }}$ such killings, a cause of enmity and rancor is generated among many people and the kindred of both the killer and the person killed are often by turns struck down as enemies. For this reason, it is agreed and granted that all Englishmen in this land shall wear, at least on the head, which they display most to view, the custom and tonsure of the English, and shall no longer dare to turn their hair in a colan. If they do so, the justiciar, sheriff, seneschal of liberties and lords in whose lordship such Englishmen are found, and their seneschals, shall distrain and compel those Englishmen by their lands and chattels, and by arrest of their body and imprisonment if necessary, to relinquish the Irish habit, at least in the head or the hair, and no more answer will be made to an Englishman having his head changed into the form of an Irishman, than would be to an Irishman if he complained in a similar case. ${ }^{\text {xliv }}$

The consequences for wearing the cúlán were thus potentially severe: English settlers who wore the cúlan lost the right to plead in the colony's central courts. They only did so temporarily, however, and once they "relinquished" their cúláns, their full legal rights as Englishmen were restored. ${ }^{x l v}$ The purpose of this law, like so many sumptuary laws, was to ensure that outward appearances faithfully reflected distinctions between different social groups - in this case the English of the colony and the Irish. This law, however, provides a more specific reason for its 
promulgation than most sumptuary laws do, and it relates to the frontier conditions of the colony. The cúlán was, if worn by a man of English descent, a misleading ethnic signifier that might lead to legal ambiguity and feuding. ${ }^{\text {.lvi }}$ The law was pragmatic in that it allowed the Irish "habit" to be worn anywhere but the head, twice conceding that Englishmen should appear English on their head and face if not in the rest of their attire. Perhaps the parliament hoped that the colonists might wear English styles from head to toe but were most concerned about the head and hair since this was the part of the body "displayed most to view".

The 1297 prohibition of the cúlán is relatively early in terms of European sumptuary law and predates known English laws by several decades. It is not its early date, however, that caused it to be so brief and simple - banning only one style. Although sumptuary law tended to become more elaborate in the later Middle Ages, Castilian, French, northern Italian, and Sicilian laws demonstrate that thirteenth-century sumptuary law - both royal and municipal - could be very detailed. ${ }^{\text {lvii }}$ For example, laws of Philip III and Philip IV of France, passed in 1279 and 1294 respectively, enumerated many social grades, as determined both by rank and wealth, and set the clothing and food appropriate for each, concentrating on luxury goods and restraining excessive spending for those below a certain social level. ${ }^{\text {xliii }}$ Laws enacted in thirteenth-century Castile were similarly expansive: the council of Alfonso X of Castile in 1258, for example, designated a range of different clothes permitted for noblemen, clergymen of the king's household and squires. ${ }^{\text {xlix }}$ These laws were concerned with social differentiation by dress, particularly at Alfonso's court, and with ensuring that luxury fabrics, precious metals, and the most expensive furs were limited to the king and nobility. They also restricted certain colors of cloth, how many cloaks or mantles a person could own and the clothing and expense associated with mourning. ${ }^{1}$ Additionally they sought to mark out Muslims and Jews by denying them certain colors and fabrics, although they do not mention a distinguishing mark like the yellow badges, hats, or other markers that Jews and Muslims were sometimes forced to wear across Europe after the Fourth Lateran Council in 1215. ${ }^{\text {li }}$ Alfonso's enactment indicates that efforts to visually differentiate 
Muslims were already in place in Castile - they were required to wear beards. Laws from other kingdoms on the Iberian Peninsula, from Hungary, and from Sicily also stipulated distinct attire or facial hair for Jews and Muslims. ${ }^{\text {lii }}$ This demonstrates that differentiation between the dominant group within a given society, and a smaller ethnic and, in the Castilian case, religious, minority with a different legal status could coexist with complex, rank-based sumptuary law that focused on luxury items. Regulations about Jewish attire were also in operation concurrently with the signaling of complex social gradations by dress in Italy, as well as Germany and France. ${ }^{\text {liii }}$ In contrast, although governing elites were surely aware that such laws were in place elsewhere in Europe, elaborate hierarchical sumptuary laws regulating the dress and appearance of different social grades within colonial society were rarely enacted in Ireland. ${ }^{\text {liv }}$

There were exceptions to this in the late thirteenth and early fourteenth-centuries but these applied to weaponry and military accoutrements and were motivated primarily by military concerns. ${ }^{\text {lv }}$ The most detailed example comes from the seigniorial enactments of Geoffrey de Geneville, lord of Trim, which set out the weaponry, armour and horses that nine types of men, divided by their wealth, were expected to have at the ready. Men with greater landholdings or moveable wealth were expected to maintain a more costly array of military paraphernalia. Significantly, no noble grades or titles are mentioned in the descriptions of these men. The narrow focus on each tenant's wealth rather than rank or other status markers mirrors the English exemplars on which these seignorial enactments were based as well as later, similar Scottish laws, and supports the notion that the military function of these enactments was paramount. They sought to ensure that men had at the ready the best military accoutrements that they could afford. ${ }^{\text {lvi }}$ And yet, an item on the same folio as that which records de Geneville's weapons enactment does concern clothing and visual display. It stipulated the fees and clothing that officials within the liberty of Trim, like the seneschal and treasurer, received on a yearly basis. ${ }^{\text {lvii }}$ An official's robes were integral to the operation of his office, as they displayed and made it manifest visually as he went about his business. Neithard Bulst, following Max Weber, 
and others have highlighted this link between the display and consolidation of status, whereby visual display was not merely a marker, but was in fact constitutive of status. ${ }^{\text {lvii }}$ Weapons enactments and material dealing with clothing are also found together in fifteenth-century Scottish parliamentary material, suggesting that for some medieval legislators there was a link between the two. A Scottish weapons acts from 1430 ordered that a man who possessed £100 worth of moveable goods should be "wele horsit and hail harnest as a gentil men aucht to be: wellhorsed and fully harnessed as a gentleman ought to be", making clear the link between rank and display by weaponry/military array. ${ }^{\text {lix }}$ Thus, although military and administrative utility was the heart of de Geneville's ordinances for the liberty, these provisions may also have been concerned to some extent with ensuring appropriate visual display for elites. Like a significant proportion of Irish sumptuary law, de Geneville's weapons enactment was positive rather than negative. That is to say, it ordered elites to spend money, rather than restraining spending or display for any group. ${ }^{\text {lx }}$

The next sumptuary law recorded in Ireland also concerned itself with divisions of status within English society, but it was generated in England, and applied to the king of England's dominions generally. It did not, therefore, directly reflect the concerns of colonists. It established staple towns in Ireland, Wales and England where wool could be bought for export and was enrolled on the Irish parliament rolls in 1326 after being sent to the mayor of Dublin by Edward II. ${ }^{\text {ki }}$ As part of its economically protectionist agenda, it mandated that both city dwellers and men and women who lived in the countryside should only buy cloth made in England, Ireland or Wales. ${ }^{\text {lxii }}$ The central concern of this law was to protect the wool industry in the king's dominions, but it made a status-based exception and allowed imported luxury fabrics for the wealthy (those who had an annual income of 40 or more) and for secular and ecclesiastical elites to distinguish them from those lower down the social scale. Later economically and socially motivated English sumptuary laws, like that from 1337 which regulated the wool trade and 
prohibited fur for those below knightly status, seem not to have been proclaimed or enforced in Ireland. ${ }^{\text {lxii }}$

The next sumptuary law promulgated by the Irish parliament was part of the famous "Statutes of Kilkenny" enacted in 1366. The relevant act mandated that chescun Engleys use la manere guise monture et appareill Engleis solonc son estat ... et qe nul Engleis quad a la value de c.s des terres ou tenements ou de rentper anch mache autrement qe en seale en guyse de Engleis et celluy qe fera le contraere et de ceo soit atteint soit son chivall forfait a nostre seignour le Roy, et son corpus a la prison tanque quil face fine a la volunte de Roy ${ }^{\text {lxiv }}$ every Englishman use the English custom, fashion, mode of riding and apparel, according to his estate... and that no Englishman who has to the value of one hundred shillings of lands or tenements, or of rent by the year, ride otherwise than on a saddle in the English fashion, and he that shall do the contrary and be thereof attaint, that his horse be forfeited to our lord the King, and his body committed to prison, until he make the fine according to the King's pleasure. ${ }^{\mathrm{lxv}}$

This was a relatively simple enactment - it did not enumerate different ranks within colonial society, although the reference to a man's “estate” suggests that legislators assumed that men's attire would vary according to their status. It also did not stipulate precisely what "English fashion" or apparel was, though it ordered that Englishmen must use saddles and provided some guidance about enforcement. ${ }^{\text {lxvi }}$ These earliest sumptuary parliamentary enactments generated within the English colony in Ireland - that against the cúlán and this encouraging English clothing - were enacted as part of larger parliamentary programs to preserve the cultural Englishness of colonists in the face of extensive assimilation. They were concerned first and foremost with ethnic distinctions, and do not directly address distinctions of rank or social status, unlike contemporary Castilian or French sumptuary laws. Even in those ordinances from 
the colony where status divisions were enumerated, like de Geneville's, military concerns were paramount and social differentiation secondary.

The Irish enactments stand in stark contrast to highly stratified sumptuary legislation passed in England in 1363. Given that the 1366 parliament was convened by Lionel, duke of Clarence, son of Edward III, when he was lord lieutenant in Ireland, rather than by a resident colonial magnate, it notable that its promulgations about dress did not resemble or even reference the sumptuary laws passed only three years before in England. ${ }^{\text {lxvii }}$ The preamble of the 1363 act bemoaned "loutrageouse et excessive apperaill des plusours gentz, contre lour estat et degree, a tresgrant destruccion et empoverissement de tote la terre: the outrageous and excessive apparel of divers people, against their estate and degree, to the great destruction and impoverishment of all the land". . ${ }^{\text {viii }}$ In order to rectify the moral and economic ills supposedly caused by people who wore "apparel not pertaining to their estate", the English parliament ordained

Que garsons, sibien servantz as Seignours come de meistere et des artificers, soient serviz de manger et de boiure, unfoith le jour, de char ou de pessone, et le remenant daltres vitailles, come de lectee, furmage, bure et autres tiels vitailles, acordantz, a lour estat: et qils eient draps pur lour vesture on chausure, dont le drape entier ne passe deux mars, et qils ne usent drape de pluis haut pris, de lour acate nautrement, ne nul chose dor, dargent, nenbroydez aymelez ne de soye, ne rien appendant des dites choses; et soient lour femmes filles et enfantr, de mesme la condicion en lour vesture et apparaille, et ne usent nulles veilles, passant la veille dusze deniers.

that Grooms, as well Servants of Lords, as they of Mysteries, ${ }^{\text {lxix }}$ and Artificers, shall be served [to eat] and drink once a Day of Flesh or of Fish, and the Remnant [of] other Victuals, as of Milk, Butter, and Cheese, and other such Victuals, according to their Estate: And that they have Clothes for their Vesture, or Hosing, whereof the whole Cloth shall not exceed Two Marks, and that they wear no Cloth of higher Price, of their buying, nor otherwise, nor nothing of Gold nor of Silver embroidered, aimeled, nor of Silk, nor nothing pertaining to the said Things; and their Wives, 
Daughters, and Children of the same Condition in their Clothing and Apparel, and they shall wear no [Veils] passing xii. d. a Veil. ${ }^{\mathrm{lxx}}$

The act elaborated in similar detail the appropriate food and apparel for "Handicraftsmen and Yeomen", "Esquires and gentlemen” below the rank of knight, knights of various incomes, and "Merchants and Citizens", focusing on expensive cloth, fur, and embellishments that were forbidden to them. ${ }^{\text {lxxi }}$ The acceptable apparel of clergy differed according to the income of the cleric, and was the same as a knight of the same income. The apparel of ploughmen, shepherds and other persons with property worth less than 40 shillings was to be of undyed or russet wool or linen and suitably inexpensive, as was their food. This law, or at least elements of it, was repealed by the English parliament in the following year, perhaps due to its unintended economic consequences, but regardless of this repeal, the law reveals the social divisions that the English parliament of 1363 perceived as most important and under threat. ${ }^{\text {lxii }}$

Like Irish sumptuary laws, this much more detailed English law sought to reinforce "visual identities" that corresponded with a person's place in society, but it focused on socio-

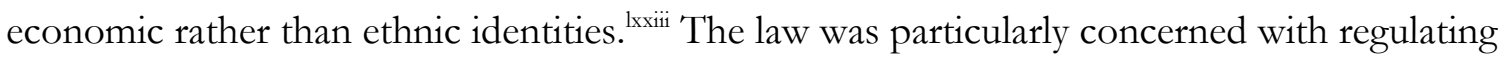
the dress of those below the highest levels of society, like grooms, esquires below the rank of knight, knights with an income of below 400 marks a year, craftsmen, merchants, yeomen, and clerks, who were neither poor nor members of the nobility to whom most luxury items were confined. Phillips has noted this attention in the English laws to what she calls "upper-middling men" and argued that these laws preserved the prestige of those highest in society, but also saved middling men from the expense of trying to maintain a luxurious wardrobe. . $^{\text {lxiv }}$ Alternatively, concern with the clothing of "middling men", which is also apparent in sumptuary legislation elsewhere in Europe, has been interpreted as a manifestation of social anxiety in the wake of the Black Death, where the established distinctions within medieval society were challenged by rising wages and what the nobility feared was an increasingly 
assertive and wealthy non-noble element of society. ${ }^{\text {lxv }}$ According to this interpretation, distinctions in dress were a way to signal and even preserve social hierarchies even when those of lower birth had the funds to buy luxury items. This argument has some merit, and depopulation may be one key driver of fashion competition. ${ }^{\text {lxxi }}$ However, the regulation of the dress of "middling men" in France and Spain predated the Black Death, and anxieties about social mobility cannot be linked solely to that event. ${ }^{\text {lxxvii }}$ Moreover Ireland, and perhaps particularly the colony, suffered during the Black Death and endured the demographic changes it engendered, but concerns about "middling men" are not discernible in most sumptuary law enacted there. ${ }^{\text {lxxiii }}$ The possible reasons for this will be examined further below.

\section{Early and mid-fifteenth century Irish sumptuary enactments}

Sumptuary laws promulgated by the Irish parliament in the fifteenth century remained brief and unelaborate. A range of motivations are discernable in the laws, but a key motivation remained ensuring that the English and the Irish were visually differentiated from one another and, more specifically, that English people did not look Irish. For example, an enactment of the Irish parliament of 1447 stated that

Per ceo qe oore nulle diversite en aray est entre lez. Angloiz marchourez et Irroiez enemyez et ensy per color dez engleshe marchourez lez Irroyez enemyes veignont de jour en autre en Anglies Countez. come Angleiez marchourez et robbent et pillent per lez hautz Chymeynez.....ordeine est et acorde qe nulle manere Homme qe voet ester accopte per homme angleiez, ne eit nulle barbe per desuis la bouche ceste assavoir quil ne eit nulle chiveux sur sone overe lippe $e^{l \times x i x}$ ensy qe le dit lippe soit un foitz. au meins rase dedeins ii semayns ou de esgale encressaunt oue le nether lyppe et si ascun homme soyt trove entre lez anglez contrary a ceo qe adonques bien list a chescun bomme de prendre eaux et lour biens come Irroiez, enemyes et eaux raunson come Irroies enemyes. inasmuch as there is no difference in apparel between the English marchers and Irish enemies, and so by colour of English marchers the Irish enemies come from 
day to day into English counties as English marchers, ${ }^{\mathrm{lxxx}}$ and rob and pillage by the high roads... it is ordained and agreed that no manner of man who will be accounted for an Englishman have any beard above the mouth, that is to say, that he have no hair upon his upper lip, so that the said lip be at least shaven within two weeks, or of equal growth with the nether lip; and if any man be found amongst the English contrary hereunto, that then it may be lawful for every man to take them and their goods, as Irish enemies, and ransom them as Irish enemies..$^{\text {lxxi }}$

The dangers of wearing a moustache as an Englishman were the same as those threatened in 1297 for wearing a cullan - temporary loss of the protection of English law. This was harsher than most sumptuary laws, which usually mandated confiscation of the offending item and/or a small fine. As in 1297, a specific and ethnically-linked justification for the act was offered: Irish enemies were not marked out visually from English marchers and so were able to enter the colony and cause destruction there. Again, this contrasts with the more general economic, moral, and social reasons usually given for sumptuary enactments elsewhere. Moustaches were frequently linked with the Irish, as in a Dublin city enactment of 1457 that forbade Irishmen and men with moustaches from lodging inside the city's walls. ${ }^{\text {lxxii }}$

Another sumptuary enactment of the 1447 parliament was justified by economic reasons and may have been modelled on a similar act from England several decades before. ${ }^{\text {lxxiii }}$ It stated that:

Le tonsure del coygne nostre Seignour le Roy ad cause divers hommes en cest terre dryland pur countre fair le dit coygne a tresgraunt lesion et destruccion du dit terre et la fesaiunce de ores bridelez. et paytrels aunxy ad gaste et consume le ore du dit terre pur le greindre partie.... ordeine est et acorde per auctorite dicest present parlement... Null home soit si hardy de ceo enavaunt de user nulle brydels de ores peytrels ne nulle autre barnez. deores en nulle lieu du dit terre forpriz. Chevalers et prelatez de seint Esglise et sy ascun homme soit trove oue ascun tielle bridle peitrelle oue ascun autre 
harnez de ores de mesme le jour qe bein list a chescun homme qe voet prendre le dit homme sone Chivalle et harnez et le possesser come sez.proprez biens.

the clipping of the coin of our lord the King has caused divers men in this land of Ireland to counterfeit the said coin, to the extreme hurt and destruction of the said land, and the making of gold bridles and poitrels [the chest piece of a horse's armour] also has wasted and consumed the gold of the said land for the greater part...it is ordained and agreed by authority of this present parliament ... [that] no man be so daring henceforward as to use any bridles of gold, poitrels, or any other harness of gold in any place of the said land, except knights and prelates of holy Church; and if any man be found with any such bridle, poitrel or any other harness of gold from the same day, that it shall be lawful for every man who will, to take the said man, his horse and harness, and to possess it as his own goods. ${ }^{\text {lxxiv }}$

This enactment is more in line with European sumptuary laws since it concerned luxury goods and reserved the right to those goods to elites (knights and bishops in this instance). It also employed a common punishment, which was the confiscation of the goods by any person who noticed the infraction and was able to seize the offending items. Still, it is rather more specific than many enactments concerning luxury goods in that it cites counterfeiting and the devaluation of coin in Ireland as the reasons for the ban on golden harnesses rather than bemoaning "great Misery and Poverty", the "grete impov[er]isshing of divers of the King['s] Sugiect[s]", "the great Destruction and Impoverishment of all the Land" or other such imprecise formulae. ${ }^{\operatorname{lxxv}}$ It is possible that there was also an ethnic motivation underlying this enactment. A letter to William Laweless, "marshal of the liege English entertainers of Ireland”, in 1435 appointed him to arrest Irish poets, musicians, and other entertainers in the colony and to confiscate any horses in their possession with gold or silver harnesses. This letter suggests that Irish entertainers may have been particularly associated with gold and silver harnesses and the 1447 parliamentary enactment 
may have sought in part to target them, restrain their displays of wealth or even discourage them from working in the colony. ${ }^{\text {lxxvi }}$ Concerns about Irish entertainers acting as spies and fomenting violence are expressed in the letter to Laweless and appear in a range of legislative material which banned Irish poets and musicians from entering the colony. lxxvii $^{\text {kn }}$

Whether or not there were ethnic associations that influenced the harness enactment, both 1447 enactments are specific, short, and relatively unelaborate, like other Irish prohibitions regulating appearance. The relative simplicity of the mid-fifteenth century Irish material and lack of attention to elaborate status hierarchies marks it out from the earliest known sumptuary law passed in one of its close neighbors, Scotland, in 1430. This detailed Scottish law stipulated appropriate attire for knights with an annual income of less than 200 marks (no restriction was placed on those who exceeded this sum), on burgesses and on yeomen and commoners, as well as on these men's wives and servants. ${ }^{\text {lxxviii }}$ It focused on luxury items like fur, precious metals and pearls, and also on the use of excessive volumes of cloth; to ensure that less cloth was used, slashed sleeves, long hoods and long trains were prohibited for the dresses of the wives and servants of commoners. Scottish burgesses, labourers and clerics (of below a certain rank) were again enjoined not to dress above their station in 1457 when detailed prohibitions concerning cloth color, use of furs, and length of cloth were issued. . $^{\text {lxxix }}$

Like the 1363 English law, the fifteenth-century Scottish acts focused on luxury materials and on signaling perceived status divisions within Scottish society. In England, detailed and lengthy sumptuary laws, similar to those of 1363, were proposed frequently in the fifteenth and early sixteenth centuries, and 7 were passed between 1463 and 1533; they divided people into rank and wealth-based groups and focused on prohibiting luxury goods and newer fashions ${ }^{\mathrm{xc}}$ Elaborate, status-based sumptuary laws continued to be passed in England in the reigns of Edward VI, Mary I and Elizabeth I before petering out in the seventeenth century. ${ }^{\text {.ci }}$ Many of these invoked economic justifications: the petition leading to the 1463 act argued that the realm was impoverished by profligate spending, and that such "excessive and inordynat 
arrayes" were "to the grete displeasure of God". xcii The 1510 act was further justified by the claim that the population resorted to robbery to so they could afford extravagant dress. ${ }^{\text {xiii }}$ The 1483 act seems to have been motivated by a variety of concerns as it ruled that no one other than a lord could wear cloth manufactured outside England, Ireland, Wales, or Calais. This protected industry in areas under crown rule but also preserved status distinctions. A modesty clause in this law dictated that only lords could wear tunics that did not cover their buttocks and "privy member". This served dual moral and social purposes. ${ }^{\text {xiv }}$ Thus, in Ireland's closest neighbours, relatively detailed and complex sumptuary laws that cited a wide range of motivations for their enactment were being passed with increased frequency in the fifteenth and early sixteenth centuries. In Ireland too, more sumptuary laws date from this period than any other, but the laws themselves remained simple and primarily concerned with the differentiation between Irish and English.

\section{Municipal enactments and the Irish mantle and saffron shirt}

This attention to ethnic differentiation through dress is apparent in municipal ordinances from Dublin from the mid-fifteenth century. Civic ordinances regulating dress appear to have been relatively common in the colony, especially in comparison to England, given how many appear in the surviving municipal records from Ireland, which are by no means voluminous. ${ }^{\mathrm{xcr}}$ Inhabitants of the colony's towns were thus subject to both parliamentary and municipal regulations regarding appearance, and both prioritized ethnic differentiation. ${ }^{\text {xci }}$ In 1466 the Dublin city council ordered that

no woman, whatsoever condicion that she be, dwellyng with in the fraunches, use [is] to werre safyrred smokes [saffron smocks] ne safyrred kewrchyes [saffron kerchiefs] ... upon the peyne of vi.d. as ofte as she can be take therwithe, one parte to the fynder, the secunde parte to the tresury, and the thride parte to the courte. cvii $^{\text {. }}$ 
It also stated that

Hit is ordeynet by the seide semble, that whatsoever dueller within the fraunches use a mantill for his dayly garment outward aftyr the post semble, to lese vi.d as ofte as he can be take therwith. ${ }^{\text {xcviii }}$

The garments that were under attack in these enactments were the mantle, the saffron shirt (léine) and saffron kerchief. ${ }^{\text {xix }}$ If an inhabitant of the franchise of Dublin, which extended some way beyond the city walls, wore these garments, they would be fined 6 pence, and the person that turned them in would receive a third of the fine. ${ }^{c}$ This method of enforcement, whereby the community was enlisted to regulate their neighbours, was employed in several other Irish laws and found in sumptuary laws in England. ${ }^{\text {ci }}$ The mantle and saffron shirt were also outlawed by the Irish parliament in the sixteenth century, and were the items most often specifically prohibited in Irish sumptuary laws. An early, but unreliable, reference suggests that saffron shirts were first banned by the Irish parliament in 1447. George Steevens claimed in a 1778 edition of All's Well that Ends Well (in his note on Shakespeare's comment about "villainous saffron") that a parliament in 1446 at Trim, county Meath prohibited these shirts. ${ }^{\text {cii }}$ It is possible that Steevens discovered a reference to a now unknown enactment of the 1447 parliament at Trim (an established but not frequent locale for meetings of the Irish parliament) and misdated it to $1446{ }^{\text {ciii }}$

The colour yellow was associated in a number of Italian and German cities with prostitution and across Europe, the colour, sometimes in the form of a yellow star or badge, was used to mark out Jewish people from the Christian population. ${ }^{\text {civ }}$ The motive for the ban on Dublin women wearing saffron-coloured clothes, and the possible parliamentary ban of 1447, probably does not relate to this more widespread and growing aversion to the colour 
yellow or to any link with prostitution. ${ }^{\mathrm{cv}}$ It relates instead to the fact that saffron dye was perceived as particularly Irish (and also associated with Highland Scots), although it is difficult to say when this association arose. ${ }^{\text {cvi }}$ By the early sixteenth-century, shirts or smocks dyed with saffron were certainly associated with Irish men and women, and visitors to Ireland from England and the continent commented upon these striking yellow garments, while legislation from 1537 also explicitly links saffron with the Irish. ${ }^{\text {cvii }}$ Fynes Moryson suggested around the turn of the sixteenth century that saffron garments were favoured by the Irish "of old" because they rarely washed and relied on the anti-louse properties of the dye. ${ }^{\text {cviii }}$ As the secretary of Lord Mountjoy, the lord deputy sent to Ireland to bring the earl of Tyrone to heel in 1600, and brother of the vice-president of Munster, Moryson was hardly an impartial observer and denigrating the Irish for being unclean fit easily into the rhetoric of Irish barbarism that his New English milieu routinely employed. ${ }^{\text {cix }}$

Whatever the reason for the Irish fondness for saffron-coloured clothes, it is clear from the sumptuary laws that some of the English of Ireland also wore them, perhaps in part because they seem to have been status symbols. ${ }^{\text {cx }}$ Many colonists, especially those who lived on or near the marches, had important Irish allies and associates and needed to cut a figure in Irish elite circles as well as in colonial and English ones. The employment of bardic poets by colonial magnates is only the best-known way that they did so, and using other Irish markers of status like these shirts, or indeed the cúlán banned in 1297, may have been another. ${ }^{\text {cxi }}$ The high cost of saffron was one factor that made these shirts high-status items, and some were also further decorated and "dressed with silke" like the saffron shirt sent by Art Óg Ua Tuathail in the late 1530s to Gerald FitzGerald, $11^{\text {th }}$ earl of Kildare. ${ }^{\text {cxii }}$ Robert Cowley, a prominent official in the Dublin administration, complained in 1537 that these shirts cost up to 5 marks a piece and that the Irish turned to robbing churches in order to afford them as festive wear around Christmas and Easter. ${ }^{\text {cxiii }}$ 
Thus, although it does not say so explicitly, it is likely that the 1466 prohibition of saffron shirts in Dublin related to the Irish associations of these garments and was driven by two longstanding concerns of the colonial elite. The first was the concern, identified in 1297 and 1447, that legal and military problems could arise when colonists were mistaken as Irish. The second was the anxiety that adopting Irish attire, or other Irish cultural traits, might erode colonists' English identity and even their loyalty to the crown. The associations between attire and identity were long-established and appearance was an important marker of ethnicity throughout Middle Ages, but these links were expressed most clearly in the later fifteenth- and sixteenth-century sources from the colony. ${ }^{\text {cxiv }}$ This was in a large part a product of the changing source material, which tended to become more descriptive in the later fifteenth century. ${ }^{\mathrm{cxv}}$

The mantle outlawed by the Dublin city council in 1466 also had a long-standing association with the Irish. Mantles were identified as an Irish fashion by Gerald of Wales in his Topography of Ireland in the late twelfth century, and as early as the ninth or tenth century they were a popular export item from Ireland to England and the continent. ${ }^{\text {cxi }}$ The Irish mantle was a large, rough, waterproof, woolen garment worn over the head and extending over the whole body. It was ideal for traveling in Irish weather, and it is no wonder that some members of the English community in Ireland adopted it for that purpose. Indeed, a parliamentary enactment banning mantles allowed that they could be worn by the English while traveling and the Dublin city enactment hints that they could be worn for some activities, just not as a "dayly garment" cxvii More than one practically-minded English official suggested that crown armies in Ireland should be issued mantles to combat the harsh weather, but economic considerations as well as their association with the Irish made this recommendation unpalatable to their fellow English administrators. ${ }^{\text {cxviii }}$

Later sixteenth-century commentators who came to Ireland from England during the Tudor reconquest provide clues about why mantles were singled out as particularly problematic by colonial legislators in the preceding century or so. ${ }^{\text {cxix }}$ The mantle could hide people's faces, 
and Fynes Moryson, paraphrasing Edmund Spenser, stated that the English of Ireland wore "mantles instead of cloaks, which mantles... being worn over the head and ears, and hanging down to the heels, a notorious villain lapped in them may pass any town or company without being known". "xx Spenser and Moryson expressed similar fears about Irish hairstyles with a long fringe over the forehead called glibbs, which were "very badd and hurtfull" because they "monstrously disguised" their wearer. ${ }^{\text {cxxi }}$ The fear of misidentification and disguise was at the heart of much sumptuary legislation, in Ireland as elsewhere. ${ }^{\text {cxii }}$ As Groebner argues, "articles of clothing served to identify and camouflage a person at one and the same time", and "discussions of dress and attire amounted to discussions of deception". cxxiii It is not surprising, therefore, that the mantle, which was associated with the Irish but also had the alarming ability to hide its wearer almost entirely, was specifically prohibited in statues and municipal ordinances. ${ }^{\text {cxiv }}$

\section{Late fifteenth-century enactments: municipal and parliamentary}

Ordinances drafted by the Waterford and Galway city councils also sought to encourage English apparel for their inhabitants, but these ordinances did not mention any specific Irish garments or styles. In 1469-70 the Waterford council ruled that if an apprentice of "Yrishe blode and nation callid or provid" wanted to be admitted to the franchise of the city, he must first prove that he had a grant of English law and status, and he must also "be of Inglish array, babite, and speche". ${ }^{\mathrm{cxx}}$ This is one of a several enactments from the later fifteenth century that encouraged the Irish who lived in English areas to adopt English clothing. An Irish parliamentary statute of 1465 encouraged the Irish living in the four counties at the heart of the English colony - Dublin, Meath, Louth and Kildare - to wear English clothing and shave off their moustaches. ${ }^{\text {cxxi }}$ The city council of Waterford may have sought to encourage assimilation by the Irish as well as combat gaelicisation among colonists when it ordered in 1477-8 that constables of suburbs of Waterford must speak good English and wear English "array" and in

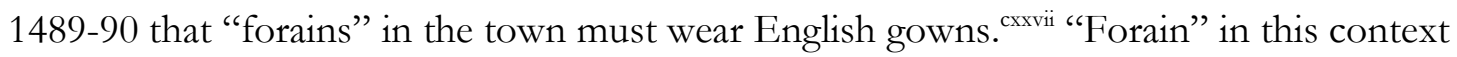


probably signifies all non-citizens, not just the Irish. ${ }^{\text {cxxviii }}$ In Galway in 1523, the council ruled that "no man shalbe made fre unlesse he can speche the Englishe tonge and shave his upper lipe wickly (weekly)"; moustaches were, as we have seen above, associated with the Irish. ${ }^{\text {cxii }}$

These laws encouraging anglicization and focusing upon the dress of the resident Irish in addition to that of the English demonstrate that sumptuary law in Ireland was not solely concerned with marking out the English of Ireland from "Irish enemies": unassimilated Irishmen who, largely, lived outside the colony's bounds. Occasionally, in the late fifteenth century particularly, it was also used to encourage the entire population of colonial Ireland, a population that comprised both English and Irish people, to look English. This chimes, to some extent, with the drive at the heart of sumptuary law to have appearance accurately reflect status, at least in the case of those resident, assimilated Irish people who had access to English law. Efforts had been made from the fourteenth century onward to make those Irish people who submitted to the English crown or received grants of English law dress in an English fashion, and so reflect their political allegiance and legal status outwardly. ${ }^{\text {cxx }}$ Many Irish residents of the colony remained outside English law, however, and distinctions among Irish people resident in the colony were not apparent in the sumptuary code, which relied on simplified visions of society and could not faithfully reflect the complexities of status and identity that characterized colonial society in the later Middle Ages. ${ }^{\text {cxxxi }}$

The drive towards integration in some later fifteenth-century Irish sumptuary laws is in stark contrast to the treatment of other marginalized groups like Jews, who throughout much of Europe were not permitted to assimilate in their dress, and were required to wear distinguishing marks like the yellow star or, in some Italian cities, a yellow "O”. cxxxii In Spain in the mid- to late-fifteenth century, this concern about distinguishing Jews from Christians extended even to conversos whose parents or grandparents had become Christian in the mass conversions of 1391. cxxxiii The Irish were Christian and there is no reason to suppose that their treatment would bear many similarities to that of Jews throughout Europe or of Iberian Muslims, who were also 
subjected to distinguishing marks. But there was in the fifteenth century a growing stigma attached to Irish parentage and a tendency to rely on descent to define who was English and who was Irish. The language of Irishness "by blood", as the sources term it, became ever more common, but it is notable that this concern with determining who was of Irish descent did not lead to a campaign to visually differentiate the Irish within the colonial population. ${ }^{\text {cxxiv }}$ The comparison with more seriously marginalized groups in Europe highlights how relatively permeable the line between Irish and English in medieval Ireland could be.

The Irish parliament next concerned itself with attire in 1494-5, in the well-known parliament overseen by Edward Poynings, the king's deputy from England. This parliament had a centralizing mission as well as an interest in preserving English culture in Ireland that was common to so many late medieval Irish parliaments. One aspect of this agenda was ensuring that lords in parliament wore robes like their English counterparts. ${ }^{\text {cxxx }}$ Several years later, in 1499, this issue was revisited and the fine for failing to wear a robe was increased to a sizable $\AA^{20}{ }^{\text {cxxxvi }}$ The act was justified "in consideracion of the kings honnour and of his high court of parliament and for the encrease of Englishe manners". Like a number of other Irish enactments, these did not discourage excessive spending, but on the contrary, ordered that lords must spend money on robes. The text of this act makes it clear that one motivation was a visual signaling of Englishness, in this case, not explicitly, but perhaps implicitly, in opposition to Irishness. ${ }^{\text {cxxvii }}$ Another, perhaps linked, motivation was to visually exhibit the prestige and "honnour" of the king and his parliament: other parliamentary enactments and municipal ordinances from Ireland and from England demonstrate a concern with appropriate official clothing as a mark of institutional and civic prestige. ${ }^{\text {cxxxviii }}$

The 1499 parliament passed a further enactment regarding appearance that was intended to make sure that colonists looked English (at least within the heart of the colony, the so-called Pale along the eastern seaboard). ${ }^{\text {cxxix }}$ The enactment mandated that 
every Lord spirituall and temporall having livelihood or benefice to the yerly value of $\mathrm{xx}$ marks within the precinct of the Englishe pale doe ride in a saddle after the englishe guise uppon peine of forfeiture of their horse and harness ... the said provision extend in like manner and form to everie merchant within this land. Provided allway that this acte extend not to any person or persons which shall ride in the deputies company to or from any hostinge or Jorney in time of were [war]. ${ }^{\mathrm{cxl}}$

Like ordinances against the saffron shirt and mantle, this enactment sought to discourage an Irish fashion, riding without a saddle, in favor of an English one. The Statutes of Kilkenny had also linked saddles with Englishness and enjoined Englishmen of a certain income to use them, as did a later ordinance of 1534 . $^{\text {cxli }}$ There was a status provision in the 1499 act, in that lords worth 20 marks and merchants were the only persons subject to it, but only two grades of person were mentioned. We might suppose that this act was motivated by military considerations as well as the desire to signal ethnicity, but the exemption given for anyone participating in a military hosting with the lord deputy here and in the 1534 ordinances makes this unlikely and we have later evidence to suggest that some of English of Ireland were actually more militarily effective when fighting with Irish weapons and without a saddle. ${ }^{\text {clli }}$

A sumptuary bill proposed but seemingly not passed at the 1499 parliament did reflect military as well as other concerns. It called for any "temporall man" of the Pale who "uses English habit" not to use Irish weapons to defend himself. ${ }^{\text {cxlii }}$ This may have been motivated by this parliament's agenda to ensure that colonists looked English in their martial display, but it may also have sprung from a desire to stop them from buying weapons from Irish craftsmen and supporting the economy of the island outside the colony. ${ }^{\text {cxliv }}$ Additionally, the bow was favored by English administrations as the most effective weapon and it encouraged archery in Ireland as well as in England and Wales by banning football and other amusements to encourage subjects to entertain themselves at the butts instead. ${ }^{\text {cxlv }}$ Thus this enactment was likely 
linked to this strategic preference for the bow over other types of weapon and the proposed weapons bill was therefore probably motivated by social, economic and military considerations.

\section{Early sixteenth-century sumptuary legislation}

Irish laws governing attire and visual display from the first half of the sixteenth century display, in general, greater similarity to English, Scottish and continental material. They became more complex and prohibited excessive spending on attire, and regulated feasting and ownership of hunting dogs, which had rarely or never been concerns of earlier legislation from the colony. For example, an enactment of the Kilkenny's city council in 1520 mandated that no woman

kepe after their childbirth no jounkery [feast] nor banquett by no manner [or] colour, upon paine of twenty shillings [from any] that will attempt the contrary. ${ }^{\text {cxlvi }}$

Sixteen years later Galway's council prohibited women who had recently given birth from making "common bancke [banquets] as in time past". cxlvii The Kilkenny council again issued restrictions on childbirth feasts in 1541 and 1580 and cited economic motives, claiming that they caused "greate impoverishing of many thenhabitants of this corporation" because "pride and comparison" made citizens overextend themselves financially. ${ }^{\text {cxlviii }}$ Much in the same way that English sumptuary law has been interpreted as saving the pride of middling men who could not afford luxury clothing, these enactments sought to protect citizens of the town from bankrupting themselves with the expensive feasts that were expected of new parents. ${ }^{\text {clix }}$ Childbirth feasts were also banned in some European towns, like Zurich, where parties called "cookie-days", hosted by a new mother, were limited to near relatives in 1422 and banned altogether in $1488 .^{\text {cl }}$

Concerns about the expense of other kinds of celebration like weddings, funerals, and even the cost associated with wooing fiancées, motivated sumptuary legislation from Scotland and the continent, but there is no Irish evidence for the regulation of weddings or funerals. ${ }^{\text {cli }} \mathrm{A}$ 
Dublin city ordinance from 1462 sought to curb women's crying within the city at "times of war" and this may be a reference to funerals or commemorations of those killed in battle, but it makes no mention of expense and most likely relates to the Irish custom of keening. ${ }^{\text {clii }}$ In terms of more general feasting restrictions, periodic prohibitions of Irish musicians and poets in the colony may have sprung in part from a desire to restrain spending and save patrons the cost of such performers at their feasts, but anxieties about Irish entertainers acting as spies were probably a greater motivation. ${ }^{\text {cliii }}$ Similar to these laws restraining feasting expenses were laws restraining expense and display by hunting. These were passed in elsewhere in Europe and dictated matter like the type of hawk or falcon each grade of man could hunt with or banned the ownership of hunting dogs for men below a certain status. ${ }^{\text {cliv }}$ By the 1530 s a law of this type was in place in the colony. It reserved hunting dogs to those who held land worth more than 40s per annum and was almost certainly based on English exemplars. Eighteen men from Meath were prosecuted for keeping dogs in the 1530 and Walter Neale, perhaps of Waterford, was prosecuted in the second half of the sixteenth century for the same offence. ${ }^{\text {clv }}$

In 1534 the colonial administration drafted the "Ordinances for Ireland" and returned to the issue of ethnicity and personal visual display through dress, the use of saddles and weaponry. These ordinances were created by Thomas Cromwell and the privy council for William Skeffington's lieutenancy, and they drew on earlier statutes of the Irish parliament but intended to ensure wider dissemination and enforcement. ${ }^{\text {clvi }}$ The ordinances dictated that no Englishman from the Pale should go to war with only a spear, but that he must also take a bow with him. "that no Englysshe man, dwellynge within the harte of the Inglyshe pale, do take any speare with hym to the felde, excepte he take a bowe and arrows, upon peyne of fortayture 6s 8d, and losyng of his spere" clvii The administration's strategic preference for the bow was again at play here, but the ethnic associations of spears with the Irish was also probably relevant. clvii The 1534 ordinances revisited saddle and apparel legislation, dictating that gentlemen with an annual income of $f^{20}$ or more "shall ryde in a saddell and weare inglyshe apparel ... except in warre". clix 
The ordinances' concern with ethnic signaling was also clear in their repetition of the prohibitions against the moustache and mantle. The ordinance added a status-based proviso, however, banning these styles only for landholding gentlemen in the colony upon the pain of a fine of 100 shillings. ${ }^{\text {clx }}$ Thus, as with other early sixteenth-century Irish laws, the ordinances incorporated more elements typical of European sumptuary law, but did not abandon the core concerns of earlier Irish sumptuary law - most of all, ethnic differentiation.

Henry VIII issued a letter regarding attire in 1536 for the city of Galway. This letter was issued in Henry's name but it reflected the views of his advisors on Ireland and/or petitions he and his council received from the colony, and it singles out many of the same fashions as the Irish legislation, like moustaches, saffron garments and mantles. It also urged men to grow their hair until it covered their ears, and wear English caps. The letter stated that townspeople should not "have anny more cloth in theyr shurtes or smockes, but five standart elles of that contry cloth". cki The regulation of fabric amounts elsewhere often related to fears about consumption, but no economic or moral justification are mentioned here, and the mention of "Englysshe cappys" and "the Englyshe facion" suggests that, again, the signaling of ethnic identity was at the heart of Henry's letter. This impression is furthered by the fact that the letter urged the inhabitants of Galway to speak English and teach it to their children. ${ }^{\text {clxii }}$

In 1537 the Irish parliament addressed many of the same concerns in "Thact for thenglishe ordre habit and langage", which mandated

that noo persone ne persons the kinges subjects within this londe .... shalbe shorne or shawen above the eares or use the wearing of any heare uppon their heddes like unto longe lockes callid glibbis or have or use any heare growing on their upper lippes callid or named a crommeall [a long moustache] or use or weare eny shirt smocke kerchour bendell neckerchour mocket or lynnen cappe coloured or dyed with saffron ne yet use or weare in eny their shirtes or smockes above seven yards of 
clothe to be measurid according to the kinges standarde; and that alsoo no woman use or weare eny kirtill or cote tucked up or embrowdred or garnysshed with sylke or couched or laid with usker ${ }^{\text {cliii }}$ after the Irishe facion; and that noo persone ne persons of what estate condicion or degre they be shall use or weare eny mantles cote or hode made after the Irishe facion. ${ }^{\text {clxiv }}$

Many of the recurring bugbears of the Irish administration - moustaches, saffron garments, the Irish "glibbs" hairstyle, and mantles - were again banned for "the king's subjects" (which included some people of Irish descent). ${ }^{\text {clxv }}$ There are elements of this enactment that could have been motivated by economic concerns or concerns about the display of social status, like the injunction against using more than seven yards of cloth to make a garment, or against luxury items like silk. However, the enactment states that silk and jewelled attire ape "the Irish fashion" and the bill that introduced this legislation explicitly linked English fashions with being a law-abiding subject. The petitions from colonial and English officials that prompted this legislation drew this same connection. ${ }^{\text {clxvi }}$ Crucially, there were no exemptions based on status provided here; all people, regardless of rank, were forbidden to wear the Irish styles described. The 1537 law was still less elaborate than late medieval English, Scottish and continental sumptuary laws, but it mentioned more specific styles than any previous law from the colony.

As already noted, some sixteenth-century Irish sumptuary laws expressed an interest in restraining expenditure. Unlike a number of fifteenth-century laws that encouraged people, especially those above a certain status or in particular offices, to spend money, the Kilkenny and Galway acts against churching feasts and an act of the Irish parliament in 1541 reveal concerns about excessive spending. ${ }^{\text {clxvii }}$ The 1541 act contained a graduated scale for the amount of fabric that could be used in a man's shirt. Lords could use to twenty cubits of cloth in their shirts, horsemen and "vassals" up to eighteen, kerne or Scots (galloglasses) up to sixteen, grooms and other servants up to twelve, and husbandmen and labourers only ten. ${ }^{\text {clxviii }}$ This, 
finally, seems like many English, Scottish and continental exemplars for sumptuary law; it is organised by rank and concerned with limiting expenditure and display. Perhaps the increasing influence of English administrators from England in Ireland in the later decades of Henry VIII's reign triggered this shift towards greater similarity to English laws. ${ }^{\text {clix }}$ A recovering economy, combined with this influx of English administrators at the elite level, may have also meant that there was more conspicuous consumption to control. ${ }^{\text {clx }}$ The increased influence of the English of England may also have encouraged the shift to less harsh punishments in the sixteenth-century laws - in 1534 fines were assigned for infractions and in 1537 punishment was merely the confiscation of the offending items. Such punishments were common in England but much milder than the loss of English law threatened in earlier laws from the colony. However, the long-standing concerns of the colonial elite were not forgotten. There was an additional prohibition made in 1541: that no man, regardless of his status, should wear a "croceis (saffron-coloured)" shirt. If they did so, they would lose the shirt and be fined 20s. ${ }^{\text {clxxi }}$ Restraining consumption and preserving the distinctions of rank may have increasingly been on the minds of lawmakers in the colony in 1541, but concerns about the use of Irish fashions, like the saffron-coloured shirts and gowns so often mentioned in earlier legislation, persisted.

\section{Laws from the colony in their European context}

Laws regarding attire and visual display that were enacted in Ireland from the later thirteenth to the mid-sixteenth century varied, banning many different items and styles, while encouraging others, and were motivated by many different agendas and concerns. And yet there are notable characteristics of the Irish material, some of which fit well with the broader European corpus, while others are peculiar to the colony. The chronological distribution of laws is similar, as the highest concentrations occur in the later fifteenth and sixteenth centuries. ${ }^{\text {clxxii }}$ Like sumptuary laws elsewhere in Europe, the Irish laws tended to become more and more elaborate over time, though they never reached the level of detail and stratification that was evident in medieval laws 
from England, Scotland, France, the Iberian Peninsula and Italian, Swiss and German cities. Some of the Irish laws employed methods of enforcement by communal policing, an enforcement strategy common in Europe overall. The urban origins of much of the legislation also reflects European trends. ${ }^{\text {clxxiii }}$ This may relate in part to the fact that urban administrations created and preserved documents that record sumptuary laws, but it is also likely that civic authorities were particularly concerned with regulating visual display. Cities were centres of wealth and provided opportunities for non-noble people to become wealthy through commerce, allowing them greater opportunity for luxurious attire and display. They were also places where differentiation by dress was necessary, since larger and more transient populations ensured that their inhabitants did not always know one another. Thus, there was more scope in urban environments for people to successfully misrepresent their status using visual markers like dress. This reminds us that one of the fundamental justifications for laws regarding attire was the same in Ireland as it was across Europe. Frank Rexroth terms it "transparency" in his comments on sumptuary laws from London. London's authorities wanted to ensure that “to see people and things should also mean to be able to categorize them properly", and the nature of urban environments made this difficult, spawning urban sumptuary law in Irish cities just as in cities across Europe. clxxiv $^{\text {. }}$

The Irish material, however, differs from much medieval sumptuary law in a number of ways. There was not a great deal of regulation of women's attire specifically. ${ }^{\text {clxxv }}$ The few mentions of women's saffron garments or gowns in Irish legislation pale in comparison to the vast quantities of legislation regulating women's dress in Italian cities, in particular, but also in Scotland and southern France. ${ }^{\text {clxxvi }}$ Sumptuary laws from England, Spain and northern France, like those from Ireland, focussed less on women's dress, as noted by Muzzarelli and Philips, among others. ${ }^{\text {clxxvii }}$ Phillips also points out that women (apart from prostitutes) were in fact exempted from much English fifteenth and sixteenth-century sumptuary law. ${ }^{\text {clxxviii }}$ No detailed examination of the variability in the level of interest in regulating women's attire across Europe 
has been attempted, although Phillips provides a useful way forward with her argument that the greater ability of English than Italian elite women to influence their families' fortunes and act in the legal, economic and political spheres (albeit sometimes informally and often in the service of their male relations) meant that clothing had less "symbolic importance" for them and they expended less cost and energy on their wardrobes. ${ }^{\text {clxxix }}$ Her argument is persuasive, and applicable to the Irish situation, where elite women, for the most part, exercised greater economic and legal independence than was usual in southern Europe (although it may be that their political influence was less than in England itself). ${ }^{\text {llxxx }}$ And yet this inattention to women's attire in some areas, like English Ireland, is multifaceted and may relate to a range of other conditions. This is one area in which where the Irish material might make a significant contribution to wider debates about differences in women's social and legal status in different regions of medieval Europe. ${ }^{\text {clxxxi }}$

It may be relevant that Ireland differed significantly even from England in that it had few witch trials, either in the medieval or the early modern period, and its late medieval civic and ecclesiastical courts seem to have rarely punished "scolds". clxxxii Witchcraft and scolding accusations were most often, though not exclusively, levelled at women, and both have been linked to the regulation of female speech and behaviour, particularly from the fifteenth century onwards. ${ }^{\text {clxxiii }}$ There is by no means a clear link between sumptuary law relating to women's dress, scolding and witch trials, but it is possible that the relative scarcity of each of these activities in the colony indicates that attitudes towards women's behaviour may have been less prescriptive there than in other areas of medieval Europe. ${ }^{\text {clxxiv }}$ Why this would be the case is not certain - particularly why Ireland would differ so markedly from England and Scotland, its closest and most comparable neighbours - but this analysis of Irish sumptuary law can play a role in assessing attitudes towards women's position and status in colonial society.

A further notable characteristic of Irish sumptuary laws also relates, at least in part, to women and to female sexual behaviour. Laws concerned with visually distinguishing prostitutes 
from other women are absent from the Irish corpus of material. Such laws were common and come from thirteenth-century France, fourteenth-century London, sixteenth-century Scotland, thirteenth, fourteenth- and fifteenth-century Italy, fourteenth-century Prague and fourteenthcentury Spain, among other locales. ${ }^{\text {clxxxv }}$ Similarly, Irish parallels to Italian laws forbidding tight trousers for men are lacking, as are bans on cut-out clothes and short jackets that did not cover the genitals and buttocks, a concern of English and German fifteenth-century legislation. ${ }^{\text {clxxxvi }}$ The regulation of clerical dress, which was also often couched in moral terms, is also mentioned rarely in Irish laws, and never in efforts to restrain luxury in clerical dress. ${ }^{\text {clxxxvii }}$ Indeed in 1447 bishops were exempted from bans on precious metals in their horse's bridles and in 1499 spiritual lords worth 20 marks a year were ordered to ride with saddles. Clerical attire could be regulated by both ecclesiastical and secular authorities, and it is a feature of much secular English sumptuary law, which stipulated what clerics could wear according to their income or rank. ${ }^{\text {clxxxviii }}$ The lack of regulation of clerical dress, prostitutes and revealing male clothing and the fact that moral and sexual justifications are not cited any of in the surviving sumptuary laws suggests that these may not have been important motivations for legislators in English Ireland. This provides a tantalizing glimpse into attitudes about prostitution and sexual morality in the colony, topics that have been largely neglected in the historiography. ${ }^{\text {clxxix }}$

Nor do Irish enactments contain the condemnations of luxury as morally deleterious common in other European sumptuary laws. There is evidence, nevertheless, that clerics in Ireland, like those elsewhere, were concerned with the corrupting influence of luxury. Poetry from this period and associated with clerical authors from the colony derided luxurious dress as a symbol of worldly vanity. ${ }^{\mathrm{cxc}} \mathrm{A}$ poem preserved in the archbishop of Armagh's registers associates extravagant dress for women and luxury items like fur and activities like feasting with the Devil and "Fleshly lustys" and registers the hope that God would destroy women's pride. ${ }^{\text {cxi }}$ These sentiments, however, did not make their way into Irish sumptuary laws. Nor were economic motivations often at the core of the Irish laws; the civic regulations banning churching feasts 
and, perhaps, the 1447 harness enactment are among the only examples since, although enactments of 1537 and 1541 had provisions that restrained spending, they, like most of the Irish material, were most concerned with ethnic signalling. ${ }^{\text {cxcii }}$ Irish sumptuary laws from the fifteenth century rarely restrained spending and a number, as mentioned above, encouraged it. Relatively little attention is paid in Irish sumptuary law to the regulation of spending on events like feasts, weddings and funerals or to hunting, and the laws that did address these matters all date to the sixteenth century. ${ }^{\text {cxiii }}$ There was also was no explicitly economically protectionist sumptuary law generated in Ireland until the very end of the sixteenth century, though staple legislation enacted in fourteenth-century England was meant to apply in the colony. ${ }^{\text {cxiv }}$ Overall, the proportion of morally or economically motivated law from the colony is small and laws that restrained expenditure tend to date from the end of the period examined here.

The proscribed penalties in some sumptuary law from the colony, particularly the loss of English law, were remarkably harsh in a European context, where loss of the offending items and fines were usual methods of punishment. ${ }^{\text {cxc }}$ The sumptuary laws of 1297 and 1447 give a clue as to why this harshness was considered necessary. Urban authorities in London, Florence, or Zurich may have feared social unrest and disorder, and misrepresentation through dress was considered potentially destabilizing across Europe - hence the need for sumptuary law. Nevertheless, in a frontier environment, ambiguous dress took on a more immediately and concretely dangerous edge. The laws examined here and other contemporary documents show that lawmakers feared that Irish interlopers could kill colonists or rob from them and spy on colonial administration. ${ }^{\text {cxci }}$ Wrongful deaths of Englishmen might lead to feuding within the colonial community, which (by the reckoning of the colonial authorities anyway) was in great peril from the Irish, and could not afford to be weakened internally. ${ }^{\text {cxvii }}$ In this atmosphere of colonial entrenchment and even paranoia, the regulation of outward appearances was a very serious matter, particularly before the later fifteenth and early sixteenth century when the prescribed penalties came more into line with English and European norms. Again, the 
increasing influence of English administrators in the sixteenth century, perhaps as well as economic recovery in the colony and increased crown investment in it, may have precipitated a move towards less harsh punishments. ${ }^{\text {cxviii }}$

The harshness of the penalties stipulated in some Irish sumptuary laws, the paucity of regulations from Ireland about women's clothing, prostitution, luxurious and high-price items, feasts and weddings, and the absence of economic and moralistic rhetoric in most laws from the colony are all notable aspects of the Irish material. The most pronounced characteristics of Irish sumptuary law when set against a wider context, however, are its lack of attention to gradations of social status within the colonial community and its recurring concern with restricting Irish styles like the mantle, saffron shirt and moustache. Linked to this is the relatively high volume of positive sumptuary law that ordered people above a certain wealth or status threshold to purchase expensive items, as well as the targeting for regulation of those highest up the social scale rather than the more usual focus on "middling men". ${ }^{\text {xcix }}$ The impulse to signal social status through clothing was not absent in the colony and was most obvious in the 1541 legislation, although it was a feature of some earlier laws. ${ }^{\text {cc }}$ Social status was clearly not the main focus of civic and central legislators, however, and only two grades of person were usually specified. The that the most elaborate class-based provisions from the colony date from the reign of Henry VIII when a growing interest in stratification within the colonial community may have been prompted by the recovering economy and the waxing influence of English administrators from England. ${ }^{\text {cci }}$

\section{Conclusions}

Surveying sumptuary laws from the colony and identifying how they fit in the European context has been one core aim of this study, but a further aim is to see what the peculiar characteristics of the Irish material can tell us the mentalities and concerns of the colonial elite. One conclusion is that ethnic differentiation and the encouragement of "English" fashions in the colony was the 
most frequently expressed concern in Irish sumptuary law. This will not be surprising to an Irish audience. The extent and nature of interethnic conflict in the colony and the often hostile attitudes of colonists towards the Irish have been core concerns of historians of medieval Ireland for centuries and Irish sumptuary laws have been viewed primarily in that context. ${ }^{\text {ccii }}$ This level of attention to ethnic markers is, however, unusual in the European context and demonstrates the adaptability of su laws in the face of local conditions. What may be more surprising for Irish medievalists is the wide range of other social, economic and military concerns that prompted laws regarding dress in Ireland, and the fact, which becomes clearer through comparison with European Jewish and Muslim populations, that governing elites were relatively open to the assimilation of many Irish residents of the colony. This assimilative drive is apparent at points throughout the colony's history but is expressed most often and most clearly in the sumptuary law from the mid-fifteenth century onward. ${ }^{\text {ciii }}$ This openness to the Irish seems remarkable in light of the dualistic worldview evinced in documents from the colony, the hostility displayed towards "Irish enemies", and the increasing focus on Irish "blood" as a marker of identity. ${ }^{\text {civ }}$ It suggests that colonial constructions of Irishness were not monolithic. Although no specific term was used regularly to describe Irish inhabitants of the colony (as a counterpoint to "Irish enemies"), the sumptuary law suggests that legislators sometimes envisioned two different types of Irish person, one peaceful type that should adopt English clothing and live in the colony, and another type that should be clearly distinguished to keep them from entering the colony and causing havoc. ${ }^{\text {ccv }}$ In this way, Irish sumptuary law reflects that central tension in the colony between assimilation - and the daily reality of economic, familial and social ties with the Irish and animosity, heightened by feelings of vulnerability and besiegement in the later Middle Ages. ${ }^{\text {ccvi }}$

Another important finding that invites explanation is that Irish sumptuary laws were generally unconcerned with signaling the distinctions of rank within the colonial community and focused not solely but for the most part on ethnic distinction. Perhaps comparison with 
contemporary frontiers could shed light on this most striking aspect of Irish sumptuary law. Wales and German settlements in Central Europe seem promising options, since both were home to colonial communities and ethnic groups that had distinctive dress and were, at least occasionally, in conflict. ${ }^{\text {cvii }}$ However, there is no ethnically-based sumptuary law from either region that is comparable to the Irish laws and it is difficult to know why this was the case. In the Welsh context, it may relate to poor source survival, as well as, perhaps, the fact that Wales was colonized earlier than Ireland and that it was more fully conquered by the heyday of sumptuary law in the later Middle Ages. ${ }^{\text {cviii }}$ Thus the Welsh and Welsh culture, despite a spike in hostility after the rebellion of Owain Glyndŵr in the early fifteenth century, were not perceived as such a serious threat as the Irish, who still controlled large areas of the island of Ireland. ${ }^{\text {ccix }}$ Wales and the Welsh marches, and the English lords of those marches, were less geographically distant from the crown and from English centers of power and were more politically fragmented among themselves than the English of Ireland: all of these factors may have made the drive to legislate about matters of ethnic differentiation weaker in Wales than in Ireland. ${ }^{\text {ccx }}$

Similarly, although ethnic animosity was undoubtedly evident in German towns in Central Europe and ethnic groups did differ by dress, there is less evidence for ethnic based sumptuary law there. The process of settlement had in many cases been less violent and interethnic hostilities may have been less acute than in Ireland. ${ }^{\text {ccxi }}$ Additionally, although many towns were dominated by elites of German descent, their manner of settlement, piecemeal and often in cooperation with local rulers, did not afford them the cohesiveness of the settler community in Ireland or provide them with a platform or single administrative body from which to legislate for the entire German settler community. ${ }^{\text {cxii }}$ The English colony in Ireland's peculiar combination of extensive cultural exchange and assimilation on the one hand, and the existence of a large unconquered portion of the island still controlled by threatening Irish lords on the other, as well as the reservation of institutional power in a self-aware, dominant group of settlers, combined to make concerns about ethnic differentiation acute and allowed these concerns to be 
expressed in sumptuary law from the colony in a way that was unusual, even on other contemporary frontiers.

And yet a deep-seated concern with ethnic signaling does not preclude attention to status-based and other types of visual distinction, as examples from elsewhere in medieval Europe demonstrate. ${ }^{\text {cxiii }}$ Other features of life in the colony may have contributed to the relative inattention to social status in the Irish sumptuary laws. One was the small size and the relative poverty of the colonial population. This is not to suggest that luxury goods were not imported into Ireland, or that Ireland was an economic backwater. The port towns of the colony had thriving trade networks, and significant mercantile populations, and the colonial economy seems to have grown in second half of the fifteenth century. ${ }^{\text {ccxiv }}$ Still, in comparison with large Italian, German, French, Dutch or English cities, these mercantile populations were small. ${ }^{\text {ccxv }}$ Added to this, constant low-level warfare and instability, combined with a failure of the colonial population to entirely recover from the disasters of the fourteenth century, ensured that the colony as a whole in the later Middle Ages was underpopulated and not wealthy. ${ }^{\text {ccxvi }}$ It may have supported only a small population that had the adequate excess income required to purchase luxury items like furs and silks so often regulated by sumptuary legislation elsewhere. Thus the regulation of luxury items may not have seemed necessary to colonial governing bodies. According to English commentators even some of the men in highest ranks of nobility in Ireland, the ninth and fourteenth earls of Desmond could not (or chose not to) purchase the luxurious clothing that was, in English eyes, appropriate to their rank. ${ }^{\text {ccxvii }}$ The economic hypothesis is given added weight by the fact that a sumptuary law that dealt explicitly with graded status divisions was passed in 1541. As argued above, this may relate to the influence of English administrators in Henry VIII's reign but may also owe much to the economic recovery of the colony and its towns from the later fifteenth century onward.

A struggling economy would explain the targeting of elites (like bishops and lords and merchants over a certain annual wealth) for positive sumptuary law, requiring them to wear 
robes and use saddles, rather than the targeting of "middling men" with negative sumptuary laws. The problem that legislators in the colony often identified was that colonists were not spending enough money on their attire, rather than that they were spending too much. Shaw argues that Scottish sumptuary law was less complex than English because Scotland was less wealthy; something similar, but even more pronounced, may have been at play in Ireland..$^{\text {ccxviii }}$ Additionally, Ireland was without a royal court. Some, though certainly not all, of the competitive consumption of the kind that was regulated by sumptuary laws was centered around royal courts. ${ }^{\text {cxix }}$ There were large seignorial households like those of the earls of Kildare and Ormond and the retinues of royal deputies in Ireland, as well as municipal buildings and civic spaces, which could all serve as venues for conspicuous display, but they were not on the same scale in terms of size or permanence as, for example, French or English royal courts. The absence of such a court in Ireland may have deprived the English of Ireland of one important place where luxury items and fashions could be displayed and admired on a regular basis. ${ }^{\text {ccxx }}$ A combination of relative poverty, small population, and the lack of a royal court may have meant that there was less conspicuous consumption to regulate than in other areas of Europe.

Two further reasons, which relate to the militarization of the colony and to its position as a frontier, may have made distinctions of dress and personal appearance less important to colonial legislators than they were to legislators in many other parts of the medieval world. The first is that prestige in the colony may have been signaled primarily by a lord's military strength and the size of their affinity or manraed, rather than by his clothes. ${ }^{\text {ccxi }}$ The Irish earls and other colonial lords had private companies of paid kerns and galloglasses, as well as allies and clients who could be called for military assistance when the need arose: these forces were necessary in the unsettled and militarized environment of late medieval Ireland. ${ }^{\text {ccxxii }}$ These military hostings would have been visually impressive and may have been the most effective and practical way for English lords in the colony to display and thereby reinforce their status. Ellis has argued that the size of one's manread was what "really mattered" to colonial society, and literary and 
administrative sources show that military service was seen as vital to status in colonial society. ${ }^{\text {ccxxiii }}$ Indeed, the king's deputy and council in Ireland felt moved to explain to Henry VIII in 1540 that his perceptions of prestige markers - including garments and coin - were not necessary applicable in the Irish situation, and that manpower was what mattered most. They argued that the Irish lord Toirdhealbhach Ó Tuathail was important enough to merit wooing into submission to the crown, despite his seeming poverty. They explained that "although it shall appere to Your Majestie, that this Thirrologh is but a wretched person, and a man of no grete power, neither having house to put his hedd in, nor yet money in his purse to by hym a garment, yet may he well make [command] 2 or 3 hundred men". ccxiiv

Heller has drawn links between a decline in the opportunity for military display in thirteenth-century France and rising interest in display through dress in the French court; in Ireland, the chance to display militarily was ever present. ${ }^{\text {ccxxv }}$ The enduring importance of military power as a mark of status may have made clothing a less potent prestige marker. This Irish case thus suggests an inverse relationship between hierarchical, class-based sumptuary law and high levels of militarization. The elaborate and hierarchical royal French sumptuary laws of 1279 and 1294 were passed in a relatively stable period before the outbreak of the Hundred Year's War and the next royal French laws were not passed until 1485, several decades after the war's conclusion. ${ }^{\text {cxxvi }}$ The first similar English laws were passed in 1363, in a period of peace with France after the treaty of Brétigny, while the next known set of English laws were passed in 1463, after the end of hostilities with France, and the first known Scottish laws passed in 1430 when Scotland was at peace with England, though in some internal turmoil. This provides some support for the idea that hierarchical sumptuary laws were generated most often (especially in their first iterations, rather than reissues) in times of at least relative peace. This makes sense given the alternative options for status display through military means, discussed above, but also the disruptive effect that warfare, at least on a large scale, can have on trade, the import of luxury fabrics, and the spending priorities of elites, who in wartime were encouraged 
by royal administrations to spend on items of military utility. Heller, for example, has attributed the relative inattention to class and status hierarchies in the Angevin-Sicilian laws passed 1290 to the Sicilian war then underway. ${ }^{\text {ccxxvii }}$ This argument cannot be pushed too far: there is no perfect correlation between peace and hierarchical sumptuary law, but it does suggest, as Heller has adverted to in her work, that warfare is one the more important influences on the shape and nature of sumptuary law.

A final possibility is that the militarization and frontier location of the colony had a significant effect on elite mentalities there and their attitudes towards social differentiation; in essence causing a reshuffling of their priorities. It may be that the dualistic worldview of the colony's elites, their constant striving to maintain Englishness in the face of extensive assimilation, their desire to extirpate Irish fashions like mantles, moustaches and saffron shirts, lessened their drive to differentiate among themselves. I would by no means suggest that social status or rank were not important within English society in Ireland, and it is clear that they were. ${ }^{\text {ccxxviii }}$ Nevertheless the difficult, embattled position of the English of Ireland in the later Middle Ages and their enmity toward the Irish outside the colony led colonial legislators to focus their attentions upon legal and ethnic distinctions between English and Irish rather than divisions within colonial society. Thus sumptuary law from the colony provides us with a window into the possible impacts of depopulation, militarization, a struggling economy, and a non-resident monarch on sumptuary law, and highlights how fundamental the frontier was to the mentalities of colonists and to their visions of the way their society was and should be organized.

I am grateful to Professor Robin Frame, Professor Andy Welsh, Professor Susie Welsh, and Dr Caoimhe Whelan for reading drafts of this paper and to Professor Sean Duffy, Professor Ralph Griffiths, Dr Matthew Stevens, Dr Peter Crooks and Dr Len Scales for assistance on aspects of 
this research. Thanks also to the conveners and participants in the James Lydon seminar at Trinity College Dublin at which this paper was first delivered.

${ }^{i}$ Sumptuary law was enacted in the classical world, and by the Carolingians, but there was a major resurgence of these laws starting in twelfth century and reaching a peak in the fifteenth and sixteenth: Kim Phillips, "Masculinities and the medieval English sumptuary laws", Gender and History 19:1 (2007), 22-42, at 23; Alan Hunt, Governance of the consuming passions: a bistory of sumptuary law (London, 1996), table 2.1, figure 2.2.

${ }^{\text {ii }}$ For discussion of the term sumptuary, see above, 4-5.

iii The papacy, bishops and other ecclesiastical authorities also issued regulations that prohibited luxury of various kinds in dress, particularly for clerics, as did Jewish religious authorities, but this paper deals primarily with regulations enacted by secular bodies. Of course secular and religious legal codes interacted, and dictates like those in the $4^{\text {th }}$ Lateran Council about Jewish and Muslim dress made their way into secular law: Louis Finkelstein, Jewish self-government in the Middle Ages (New York, 1924), 292-4; David Nirenberg, "Conversion, Sex, and Segregation: Jews and Christians in Medieval Spain”, The American Historical Review 107:4 (2002), 1065-1093, at 1072.

iv Diane Owen Hughes, "Sumptuary law and social relations in Renaissance Italy" in Paula Findlen (ed.), The Italian Renaissance: the essential readings (Oxford, 2012), 124-50, at 130.

"Hunt, Governance of the consuming passions, 104; Baldwin, "Sumptuary legislation", ii; Neithard Bulst, "Zum problem stadtischer und territorialer kleider-, Aufwands- und luxusgesetzgebung in Deutschland" in André Gouron and Albert Rigaudière (eds), Renaissance du pouvoir législatif et genèse de l'état (Montpellier, 1988), 20-57, at 48-50; Neithard Bulst, "Vom Luxusverbot zur Luxussteuer. Wirtschafts-und sozialgeschichtliche Aspekte von Luxus und Konsum in der Vormoderne" in Michael Prinz (ed.), Der lange Weg in den Uberfluss: Anfange und Entwicklung der Konsumgesellschaft seit der Vormoderne (Paderborn, 2003), 47-60, 56-7; The Statutes of the Realm i (9 vols, London, 1810), 279. 
${ }^{\text {vi }}$ Maria Giuseppina Muzzarelli, "Reconciling the privilege of a few with the common good: sumptuary laws in medieval and early modern Europe", Journal of Medieval and Early Modern Studies 39:3 (2009), 597-617, at 609. This is also true of sumptuary laws outside Europe: Donald H. Shively, "Sumptuary regulation and status in early Tokugawa Japan", Harvard Journal of Asiatic Studies, 25 (1964-5), 123-64.

vii Claire Sponsler, "Narrating the social order: medieval clothing laws", Clio 21:3 (1992), 265-83, at $282-3$.

viii Gender signaling was rarely regulated, perhaps because societal pressure against cross-dressing was so intense that it rarely occurred. However, there was legislation forbidding women to wear men's clothes in Speyer in 1356: Bulst, “Zum problem”, 43.

${ }^{\text {ix }}$ Muzzarelli, "Reconciling the privilege", 601, 612; Sarah-Grace Heller, “Angevin-Sicilian Sumptuary Statutes of the 1290s: Fashion in the thirteenth century Mediterranean" in Robin Netherton and Gale R. Owen-Crocker (eds), Medieval Textiles 11 (Suffolk, 2015), 79-97, at 96-7; Sponsler, "Narrating the social order," 265-83; Frances Shaw, "Sumptuary legislation in Scotland", Juridical Review 24 (1979), 81-115, at 108-09.

${ }^{x}$ Artwork, devotional material and literary works, particularly bardic poetry, commissioned by colonial elites survives from Ireland, but there is nothing on the scale of, for example, England or Italy. For what survives on the literary side, see Katharine Simms, "Bards and barons: the Anglo-Irish aristocracy and the native culture" in Robert Bartlett and Angus MacKay (eds), Medieval frontier societies (Oxford, 1989), 177-97; John Thompson, "Books beyond England" in Alexandra Gillespie and Daniel Wakelin (eds), The Production of Books in England, 1350-1500 (Cambridge, 2011), 259-75; Caoimhe Whelan, "James Yonge and the writing of history in late medieval Dublin” in Seán Duffy (ed.), Medieval Dublin XIII (Dublin, 2013), 183-95.

${ }^{x i}$ Kristen Burkholder and Hilary Doda have used testamentary and other materials to argue against the established view that English sumptuary laws were largely ineffective. In the Irish case, relatively few wills and very little information about enforcement survives: Hilary Doda, 
“Saide monstrous Hose': compliance, transgression and English sumptuary law to 1533", Textile History 45:2 (2014), 171-91, at 172-4, 178-9; John Scattergood, "Fashion and morality in the late Middle Ages" in Reading the past: essays on medieval and renaissance literature (Dublin, 1996), 240-57, at 248; Kristen Burkholder, "Dress and textiles in English wills" in Robin Netherton and Gale Owen-Crocker (eds), Medieval clothing and textiles 1 (Woodbridge, 2005), 133-54, at 152. For the continent, enforcement records compiled by Muzzarelli show that Italian cities did prosecute offenders: Muzzarelli, La legislazione suntuaria, 47-8, 60-9, 84-101. See for an alternate view Jane Bridgeman, "Pagare le pompe": why Quattrocento sumptuary laws did not work" in Letizia Panizza (ed.), Women in Italian Renaissance culture and society (Oxford, 2000), 209-26; Catherine Kovesi Killerby, "Practical problems in the enforcement of Italian sumptuary law, 1200-1500" in Trevor Dean and K. P. Lowe (eds), Crime, society and the law in Renaissance Italy (Cambridge, 1994), $99-120$.

xii Catherine Kovesi Killerby, Sumptuary Law in Italy, 1200-1500 (Oxford, 2002), 6; James Brundage, "Sumptuary laws and prostitution in late medieval Italy", Journal of Medieval History 13 (1987), 343-355, at 352-3; Sponsler, "Narrating the social order", 283; Wilson, "Common threads", 143.

xiii The beginning date at the first sumptuary law is a natural one, but a reasonable end date is more difficult to determine: 1541 marks a significant change in Ireland's constitutional status as Henry VIII was declared king of Ireland and a major sumptuary law was passed in the colony in this year.

xiv Margaret Rosenthal identified the difficulties with comparative work on sumptuary law across such broad linguistic spaces and suggests a collaborative approach. This is, in part, an offering in that direction: Rosenthal, "Cultures of clothing in later medieval and early modern Europe", Journal of Medieval and Early Modern Studies 39:3 (2009), 459-81, at 476.

${ }^{x v}$ Scattergood, "Fashion and morality in the late Middle Ages", 249-57; Brundage, "Sumptuary laws and prostitution in late medieval Italy", 346-7; Jeffrey Widmayer, "The sumptuary laws of 
MC Montpellier H119”, Romance Notes 46:2 (2006), 131-41, at 132; Muzzarelli, "Reconciling the privilege", 598. See also notes 171 and 172 below.

${ }^{\text {xvi }}$ See, for the first centuries of the colony's history: Robin Frame, Colonial Ireland, 1169-1369 (2 $2^{\text {nd }}$ edn, Dublin, 2012).

${ }^{x v i i}$ Sparky Booker, Cultural exchange and identity in late medieval Ireland: the English and Irish of the four obedient shires (Cambridge, 2018); Brendan Smith, "The concept of the march in medieval Ireland: the case of Uriel", Proceedings of the Royal Irish Academy 88c (1988), 257-69; P.J. Duffy, "The nature of the medieval frontier in Ireland", Studia Hibernica 22-23 (1982-3), 21-38; John Morrissey, "Cultural geographies of the contact zone: Gaels, Galls and overlapping territories in late medieval Ireland", Social and cultural geography 6:4 (2005), 551-66.

xviii It is difficult to settle on a satisfactory collective name for the settlers who came from Wales and England to Ireland in the late twelfth century. This is even more the case for their descendants, who intermarried with and adopted many of the cultural and social practices of the Irish. This study calls them 'settlers', 'colonists' and 'English of Ireland', as these are closest to the names and terms they favoured for themselves. For a discussion of these terms, see: Booker, Cultural exchange and identity, 8-9.

xix They must also rely in many cases on secondary materials as a guide for the non-Irish material. xx The "British Isles" approach is now dominant in medieval Irish historiography: Robin Frame, Ireland and Britain, 1170-1450 (London, 1998); Steven Ellis, Tudor frontiers and noble power: the making of the British state (Oxford, 1995).

${ }^{x x i}$ R. R. Davies, The Age of Conquest: Wales, 1063-1415 (Oxford, 2000), 443-58.

xxii R. R. Davies, "Presidential address: The peoples of Britain and Ireland 1100-1400, iii", Transactions of the Royal Historical Society 6 (1996), 1-23, at 6. There is evidence for the enforcement of English sumptuary law in Wales, but the few surviving borough ordinances from Wales, like those of Cowbridge (which parallel those from Kenfig and Neath closely) contain no sumptuary material: R.R. Davies, Lordship and society in the march of Wales (Oxford, 1978), 137; The Borough 
ordinances of Cowbridge, ed. Patricia Moore (Glamorgan, 1986); The Statutes of W ales, ed. Ivor Bowen (London, 1908), 32-45. Many thanks to Professor Ralph Griffiths and Dr Matthew Stevens for their comments on the Welsh material.

xxiii K.W. Nicholls, "Celtic contrasts": Ireland and Scotland", History Ireland 7:3 (1999), 22-6; Steven Ellis, Nationalist historiography and the English and Gaelic worlds in the late Middle Ages", Irish Historical Studies 25:97 (1986-7), 1-18, at 6.

xxiv Bartlett and MacKay, Medieval frontier societies; Robert Bartlett, The Making of Europe: conquest, colonization and cultural change, 950-1350 (London, 1993). The available English historiography of central and Eastern Europe rarely addresses sumptuary law: Jaroslav Miller, Urban society in eastcentral Europe, 1500-1700 (Aldershot, 2008); Alan V. Murray (ed.), The clash of cultures on the medieval Baltic frontier (Farnham, 2009), especially Paul Knoll, “The Polish-German frontier”, 151-74. A notable exception focuses on religious rather than ethnic distinctions, although the two are linked: Nora Berend, "Medieval patterns of social exclusion and integration: the regulation of non-Christian clothing in thirteenth-century Hungary", Revue Mabillon 8 (1997), 155-76.

xxv Muzzarelli, "Reconciling the privilege", 597-617; Laurel Ann Wilson, “Common threads: a reappraisal of medieval European sumptuary law" in Elizabeth Lambourn (ed.), Legal encounters on the medieval globe (Kalamazoo, 2017), 141-65; Hunt, Governance of the consuming passions, 75; Frances Elizabeth Baldwin, "Sumptuary legislation and personal regulation in England", unpublished Ph.D thesis (Johns Hopkins University, 1923), 209. This argument is unconvincing since the bulk of sumptuary legislation enacted in the colony sought to control the clothing worn by the English of Ireland, not by the Irish.

xxvi The term sumptuary law comes from the Latin leges sumptuariae, used the ancient Roman context to mean excessive spending and to describe the laws that restrained expense in food, celebrations and dress: Janos Erdody, "Parsimonia atque tenuitas apud veteres custodita sunt': Certain aspects of laws preventing extravagant expenditures in Roman law", Journal on European History of Law 8:1 (2017), 103-110, at 103-4. 
xxvii The historiography of "sumptuary" law rarely confines itself only to laws that restrained spending. See, of many examples, Killerby, Sumptuary Law in Italy and Sarah Grace Heller, "Limiting yardage and changes of clothes: sumptuary legislation in thirteenth century France, Languedoc and Italy" in E. Jane Burns (ed.), Medieval fabrications: dress, textiles, clothwork, and other cultural imaginings (Houndmills, 2004), 121-36. This is a broader definition than that recently advocated by Wilson: she argues that only prohibitive laws can be called sumptuary, and not prescriptive dress codes. Both, however, were used for the same purposes of social and ethnic differentiation in Ireland: Wilson, "Common threads", 142-3 xxviii Cosgrove provides a summary of the historiography up to the publication of his 1983 article: Art Cosgrove, "Parliament and the Anglo-Irish community: the declaration of 1460" in Art Cosgrove and J.I. McGuire (eds), Parliament and community: historical studies xiv (Belfast, 1983), 2541 , at $26-7$.

${ }^{x x i x}$ A. J. Otway-Ruthven, History of medieval Ireland $2^{\text {nd }}$ edn (New York, 1980), 190; H.G.

Richardson and G.O. Sayles, The Irish parliament in the Middle Ages (Philadelphia, 1952), 244-45. ${ }^{x x x}$ The original appears in italics, with scribal abbreviations expanded, and the relevant editor's translation following. In those cases where the translation is the author's own, this will be noted: Cosgrove, "Parliament and the Anglo-Irish community", 28; Robin Frame, "Les Engleys nées en Irlande': the English political identity in medieval Ireland", Transactions of the Royal Historical Society, sixth series, 3 (1993), 83-103, at 99-100.

xxxi Paul Brand, "King, church, and property, the enforcement of restrictions on alienations into mortmain in the lordship of Ireland in the later Middle Ages" in Brand (ed.), The making of the common law (London, 1992), 245-66, at 247-8.

xxxii Statutes, Ordinances, and Acts of the Parliament of Ireland: King John to Henry V, ed. Henry F. Berry (Dublin, 1907) [Stat. Ire., John- Hen. V], 282-3.

xxxiii Frame, “Les Engleys", 99-101; Stat. Ire., John- Hen. V, 254, 299, 301, 323, 493-9, 507-9. 
xxxiv Cosgrove, "Parliament and the Anglo-Irish community", 30; James Lydon, The lordship of Ireland in the Middle Ages, $2^{\text {nd }}$ edn (Dublin, 2003), 203-5; Steven Ellis, Ireland in the age of the Tudors, 1447-1603 (Harlow, 1998), 61-2, 93, 144, 188.

xxxv Frame, “Les Engleys", 99-100; James Lydon, "Ireland and the English crown, 1171-1541”, Irish Historical Studies 29:115 (1995), 291-2, n. 52.

${ }^{\text {xxxvi }}$ Ellis, Ireland in the age of the Tudors, 225.

xxxvii S.P. Hen. VIII, iii, no. 2, 457-8.

xxxviii Stat. Ire., John- Hen. V, 367-71, 389; Liber Primus Kilkenniensis, ed. and trans. A.J. OtwayRuthven (Kilkenny 1961), 132-4; Calendar of the ancient records of Dublin, ed. J.T. Gilbert (18 vols, Dublin, 1889) [Anc. rec. Dublin], i, 172-3.

xxxix “Close roll 23 Edward III", CIRCLE: A calendar of Irish chancery letters, chancery.tcd.ie [CIRCLE].

${ }^{x 1}$ Stat. Ire., John- Hen. V, 439; Stat. Ire. Hen. VI, 21, 29, 201, 235, 294.

xli This legislation is discussed on 10-11 above.

xlii William Sayles, "Early Irish attitudes towards hair and beards", Zeitschrift für Celtische Philologie 44 (1991), 154-89, at 157, 164-5; Seán Duffy, “The problem of degeneracy” in James Lydon (ed.), Law and disorder in thirteenth-century Ireland: the Dublin Parliament of 1297 (Dublin, 1997), $87-$ 106, at 88; Robert Bartlett, "Symbolic meanings of hair in the Middle Ages", Transactions of the Royal Historical Society 6 (1994), 43-60, at 46.

xliii This refers to the fact that the Irish were, in general and without a grant of English law, considered as being outside English law. Thus, if a colonist killed an Irish person, he would not usually be subject to felony prosecution. Such deaths could be resolved by a monetary payment instead, in accordance with Irish practice (though of course payment in recompense for death or injury was also a feature of contemporary English arbitration procedures). See Booker, Cultural exchange and identity, chapt. 3; Peter Crooks, "Factions, feuds and noble power in the lordship of Ireland, c. 1356-1496", Irish Historical Studies 35:140 (2007), 425-54, at 450. 
xliv The translation and transcription are both Connolly's: Philomena Connolly, "Enactments of the 1297 parliament" in James Lydon (ed.), Law and disorder in thirteenth century Ireland: the Dublin Parliament of 1297 (Dublin, 1997), 158-61.

xlv The enactment does not state this explicitly, but the wording suggests that no penalty would apply to Englishmen who used to have cúláns.

xlvi Duffy, "Degeneracy", 88; Heller, "Limiting yardage”, 130.

xlvii Detailed municipal ordinances were enacted in Bologna in 1288, listing a great many styles and types of celebration to be regulated: Maria Guiseppina Muzzarelli (ed), La legislazione suntuaria: secoli xiii-xvi: Emilia-Romagna (Rome, 2002), 50-8. The laws of Parma provide a representative example of sumptuary law becoming more and more elaborate from the $13^{\text {th }}$ century into the early modern period: Daniela Romagnoli, "Parma e Piacenza" in Muzzarelli, La legislarione suntaria, 449-55.

xlviii H. Duplés-Agier, “Ordonnance somptuaire de Philippe le Hardi”, Bibliothéque de lÉcole des Chartes, xv (1854), 176-81; Frédérique Lachaud, "Dress and social status in England before the Sumptuary laws" in Peter Coss and Maurice Keen (eds), Heraldry, Pageantry and Social display in Medieval England (Woodbridge, 2002), 104-123, at 107; Sarah-Grace Heller, “Anxiety, hierarchy, and appearance in thirteenth-century sumptuary laws and the Roman de la Rose”, French Historical Studies, 27:2 (2004), 311-348, at 312-32.

${ }^{\text {xlix }}$ For Alfonso and his legislative activities see Angus MacKay, Spain in the Middle Ages: from frontier to empire, 1000-1500 (New York, 1977), 98-100; Jerry Craddock, “The legislative works of Alfonso el Sabio" in Robert Burns (ed.), Emperor of Culture: Alfonso X the Learned of Castile and bis thirteenth-century renaissance (Philadelphia, 1990), 182-97. Other detailed Castilian laws are described in Wilson, "Common threads", 152-3. 
${ }^{1}$ Anon., "A thirteenth-century Castilian sumptuary law", The Business History Review 37, nos 1-2 (1963), 98-100, at 98; Heller, “Angevin-Sicilian Sumptuary Statutes of the 1290s”, 79-97.

${ }^{\text {li }}$ The Council, under Pope Innocent III, ruled that Jews and Muslims must wear an identifying mark of some kind to stop Christians from interacting and having sexual intercourse with them unknowingly: Nirenberg, "Jews and Christians in medieval Spain”, 1072, 1079; Diane Owen Hughes, "Distinguishing signs: ear-rings, Jews and Franciscan rhetoric in the Italian renaissance city", Past \& Present 112 (1986), 3-591, at 16-18; Nicholas Vincent, "Two letters on the wearing of the Jewish badge, 1221 and 1229”, Jewish Historical Studies 34 (1994-6), 209-24, at 209; Nora Berend, At the gate of Christendom: Jews, Muslims and "Pagans" in medieval Hungary, c. 1000-c.1300 (Cambridge, 2001), 161-2.

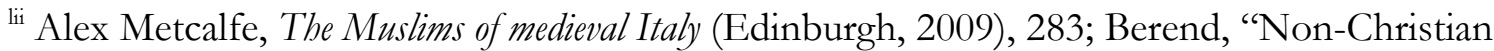
clothing in Hungary", 171, n. 81; J. N. Hillgarth, The Spanish Kingdoms, 1250-1516 (2 vols, Oxford, 1976-8), i, 167-9; Heller, “Limiting Yardage”, 124;

liii Muzzarelli, "Reconciling the privilege", 607.

liv Lachaud suggests that Edward I and his advisors would have been well-aware of the thirteenth-century French sumptuary laws, and the justiciar who headed the 1297 Parliament, John Wogan, had close ties with Edward and the English court. Wogan was, in fact, with Edward in Scotland for much of 1296: Lachaud, "Dress and Social status", 107; C.V. Langlois, "Project for taxation presented to Edward I", English Historical Review, 4 (1889), 517-21; DuplésAgier, “Ordonnance somptuaire”, 176-81; Ronan Mackay, “John Wogan”, Dictionary of Irish Biography, (eds) James McGuire and James Quinn (Cambridge, 2009), http://dib.cambridge.org/ $[D I B]$.

${ }^{1 v}$ Frame notes a simple early example of an Irish parliamentary enactment of 1297 which stipulated that tenants who held 20 pounds worth of land must have a horse and armour at the ready to pursue felons: Robin Frame, "Military service in the lordship of Ireland 1290-1360: 
institutions and society on the Anglo-Gaelic frontier" in Bartlett and MacKay, Medieval frontier societies, 101-26, at 108 .

lvi A likely exemplar is the Statute of Winchester of 1285, which was enrolled in Ireland in 1308, but which a transmarine landholder and sometime royal official like de Geneville would have been well aware of before its official Irish enrollment; Stat. Ire., John to Henry V, 254-7; Beth Hartland, "Vaucouleurs, Ludlow and Trim: the role of Ireland in the career of Geoffrey de Geneville (c. 1226-1314)", Irish Historical Studies 32:128 (2001), 457-77.

lvii Many thanks to Robin Frame for this reference and for his comments on the English parallels. See Frame, "Military service in the lordship of Ireland", 108-9; Calendar of the Gormanston register, ed. James Mills and M.J. McEnery (Dublin, 1916), 182.

lviii Bulst, "Vom Luxusverbot zur Luxussteuer", 47-8; Heller, “Anxiety, Hierarchy, and appearance", 330; Susan Crane, The performance of self: ritual, clothing and identity during the Hundred Years War (Philadelphia, 2002), 9.

lix The Scottish acts can be found in the original Scots and in translation at Record of the parliaments of Scotland to 1707: http:/ /www.rps.ac.uk, see 1426/20 and 1430/12-18.

${ }^{1 x}$ Gormanston register, 182.

${ }^{1 x i}$ In Ireland these were Dublin, Cork and Drogheda: Stat. Ire., John- Hen. V, 315; Michael Prestwich, The three Edwards: war and state in England, 1272-1377 (London, 1980), 95.

lxii Stat. Ire., John-Hen. V, 318-19.

lxiii Doda, "Saide monstrous hose", 175. Scottish wool was included as "home industry" in 1337: the law applied only to those people in "the King's Power" in Scotland, and perhaps only to wool made in areas considered "under the king's power". This makes sense in light of the fact that in 1337 Edward III claimed overlordship over Scotland and some regions of Scotland were under control of his puppet king Edward Balliol: Baldwin, "Sumptuary legislation", 21-3; Statutes of the Realm, i, 280-1; Bruce Webster, "Edward Balliol", Oxford Dictionary of National Biography (Oxford, 2004), online edn, http://www.oxforddnb.com [ODNB]. 
Ixiv The original Irish parliament rolls were destroyed in 1922 and only the nineteenth century transcriptions and resulting editions survive. These were published with the scribal abbreviations intact, and the author has expanded these to abbreviations here to provide a full transcription of the text in the original language.

lxv Stat. Ire., John- Hen. V, 434-5.

${ }^{\text {lxvi }}$ Clauses 35 and 36 gave details of how the enactments passed in Kilkenny should be enforced using both secular and ecclesiastical censures: J.A. Watt, "The Anglo-Irish colony under strain" in F. X. Martin, F. J. Byrne, et al. (eds), A New History of Ireland, 9 vols (Oxford, 1972-2011), ii, 386.

lxvii A statute drafted and passed in the Irish parliament in 1351 referenced a "statute in England" that related to the matter at hand (the fees of marshals in English courts), while the statutes of Kilkenny themselves refer to 3 different English statutes that were relevant to particular enactments: Stat. Ire., John- Hen. V, 384-5, 438-9, 454-5, 460-1. For Lionel, see Frame, Colonial Ireland, 147-50; Edmund Curtis, "The Viceroyalty of Lionel, Duke of Clarence, in Ireland, 13611367 (continued)", Journal of the Royal Society of Antiquaries Ireland 8:1 (1918), 65-73, at 65-71. Some in his retinue were experienced administrators, many in their localities, and would have been responsible for enforcing sumptuary laws there: Lydon, The lordship of Ireland, 157; Frame, Colonial Ireland, 149; Carole Rawcliff, "Ralph Stafford", ODNB; Gerald Harriss, Shaping the nation: England, 1360-1461 (Oxford, 2005), 167.

lxviii The petition that presaged the act also cited economic concerns: Baldwin, "Sumptuary legislation", 38.

${ }^{\text {lxix }}$ Mysteries refers to guild members and merchants: Burkholder, "Threads bared”, 144-5.

Ixx Statutes of the Realm, i, 380-2.

lxxi The status implications of fur were finely graded in this 1363 act: Julia Emberley, The cultural politics of fur (Ithaca, 1998), 46-7. 
lxxii Burkholder argues that the repeal was only partial and may have only applied to import and export restrictions, not the other elements of the law. Doda suggests that opposition to the law may have been the result of the trading monopolies it encouraged: Burkholder, "Threads bared", 144-5; Doda, "Saide monstrous hose", 175. The wording of the preamble of the repeal suggests that the entire act was repealed, but the body of the act only discusses importing and exporting: Statutes of the Realm, i, 383.

lxxiii Malcolm Barnard, Fashion as communication (Abington, 1996), 109.

lxxiv Phillips, "Masculinities and sumptuary laws", 28-9.

${ }^{\text {Ixx }}$ Sponsler, "Narrating the social order", 280-3; Brundage, "Sumptuary laws and prostitution in late medieval Italy”, 352-3; Samuel Cohn, "After the Black Death: Labour legislation and attitudes towards labour in late medieval western Europe”, The Economic History Review 60:3 (2007), 457-85, at 465-6, n. 44,47, 480-1; William M. Bowsky, “The impact of the Black Death upon Sienese government and society", Speculum 39:1 (1964), 1-34, at 28. A French royal law of 1485 concerned itself with the regulation of these "upper middling men": Harry Miskimin, Money and power in fifteenth-century France (New Haven, 1984), 118-19.

${ }^{\text {lxxi }}$ Cannon linked both rapid depopulation and rising population to fashion: Aubrey Cannon, "The cultural and historical contexts of fashion" in Anne Brydon and Sandra Niessen (eds), consuming fashion: adorning the transnational body (Oxford, 1998), 23-38, at 26-7

lxxvii Alfonso's law sought to reserve luxury items for high-status clerics like bishops, nobility and to royalty: Anon., “A thirteenth-century Castilian sumptuary law”, 99-100. Owen Hughes argues that Philip the Fair's 1294 sumptuary law may have been prompted by a desire to keep a rising "bourgeoisie" from aping noblemen's clothing: Diane Owen Hughes, "Regulating women's fashion" in Christiane Klapisch-Zuber (ed.), A bistory of women in the west: silences of the Middle Ages (Cambridge, MA, 1992), 136-58, at 139.

lxxviii Maria Kelly, A bistory of the Black Death in Ireland (Stroud, 2001), 91. 
lxxix The words 'overe lippe' and 'nether lyppe' are Middle English rather than French; the Law French of the parliament rolls, like other administrative and legal documents from this period, routinely used non-French words, including Latin, English and occasionally Irish words, particularly very specific and technical terms.

${ }^{\text {lxxx }}$ A marcher was an English inhabitant of the march, a wide swathe of borderland where the colony abutted areas under the control of Irish lords: Patrick J. Duffy, "The nature of the medieval frontier in Ireland”, Studia Hibernica 22-3 (1982-3), 21-38; Brendan Smith, "The concept of the march in medieval Ireland: the case of Uriel", Proceedings of the Royal Irish Academy 88c (1988), 257-67.

lxxi Statute rolls of the parliament of Ireland, reign of King Henry VI, ed. Henry F. Berry (Dublin, 1910) [Stat. Ire., Hen. VI], 88-9.

lxxxii Anc. rec. Dublin, i, 298. For these moustaches see the Irish figures in Albrecht Durer's sixteenth-century drawing, printed in H.F. McClintock, Old Irish and Highland dress, $2^{\text {nd }}$ edn (Dundalk, 1950), pl. 17; Laurent Vital, Archduke Ferdinand's visit to Kinsale in Ireland, an extract from Le Premier Voyage de Charles-Quint en Espagne, de 1517 à 1518, ed. Dorothy Convery (Cork, 2012), 288 [The Corpus of Electronic Texts (CELT), www.ucc.ie/celt].

lxxxiii Baldwin, “Sumptuary legislation”, 94-5; “Item VII, 8 Henry V: December 1420”, Parliament Rolls of Medieval England, eds Chris Given-Wilson, Paul Brand, Seymour Phillips, Mark Ormrod, Geoffrey Martin, Anne Curry and Rosemary Horrox (Woodbridge, 2005) [https://www.britishhistory.ac.uk/no-series/parliament-rolls-medieval]. This 1420 parliament was, like the 1447 Irish Parliament, very concerned with the scarcity of coin and addressed this issue in several enactments.

lxxiv Stat. Ire. Hen. VI, 91.

${ }_{\text {Ixxx }}$ Statutes of the Realm, ii, 468; Statutes of the Realm, iii, 8-9; Statutes of the Realm, i, 380-2. Letters of 1414 and 1423 evince concern with scarcity of precious metals and forged, clipped and devalued coin: "Patent Roll 2 Henry V”, no. 199; "Patent Roll 1 Henry IV”, no. 115, CIRCLE. A mint 
was established in Ireland to officially debase the Irish coinage in response to the shortage of precious metals some thirteen years after the 1447 enactment: Steven Ellis, "The struggle for control of the Irish mint, 1460-c.1506”, Proceedings of the Royal Irish Academy 78c (1978), 17-36. lxxxvi "Patent Roll 13 Henry VI", no. 86, CIRCLE.

lxxxvii Stat. Ire., John-Hen, 447; State Papers Hen. VIII, iii, no. 2, 450, 508; David Greene, "The Professional poets” in Brian Ó Cuív (ed.), Seven centuries of Irish learning, 1000-1700 (Cork, 1961), 38-50, at 38-9; T. O’Rahilly, "Irish poets, historians and judges in English documents, 15381613" Proceedings of the Royal Irish Academy 36c (1921-4), 86-120, at 86.

lxxxviii The survival of Scottish parliamentary material is poor, and earlier legislation may have been lost to the historical record: Shaw, "Sumptuary legislation in Scotland", 81-3. A translation and the original Scots are available at Record of the Parliaments of Scotland to 1707, hosted by the University of St Andrews at http://www.rps.ac.uk/trans/1430/12.

lxxix Shaw, "Sumptuary legislation in Scotland", 83-4.

xc Baldwin, "Sumptuary legislation", 84-202; Phillips, "Masculinities and sumptuary laws", 33-7; Doda, "Saide monstrous hose", 176; Statutes of the Realm, ii, 399, 468; Statutes of the Realm, iii, 8-9, 179-80. There may have been acts passed between 1363 and 1463 that are not preserved in the English parliament rolls: Burkholder, "Threads bared”, 145, n. 40.

xci “The briefe content of certayne actes of Parliament agayst thinordinante use of apparel (1559)", and "A declaration of the Queenes Maiesties will and commaundement, to haue certaine lawes and orders put in execution against the excesse of apparel (1588)", Early English Books Online (EEBO).

xcii Baldwin, "Sumptuary legislation", 118-19.

xciii Statutes of the Realm, iii, 121-3.

xciv Statutes of the Realm, ii, 468-70.

${ }^{\text {xcv }}$ Muzzarelli claims that paucity of municipal sumptuary law is an English peculiarity, and Robin Frame suggests that it may relate to England's unusual level of centralisation. It is striking that a 
survey of the civic records for the large English towns of Norwich and Bristol turn up no sumptuary ordinances, while the much less voluminous records for the smaller towns of Galway and Waterford do: Muzzarelli, "Reconciling the privilege", 606; The great white book of Bristol, ed. Elizabeth Ralph (Bristol, 1979); The little red book of Bristol, ed. Francis Bickley (Chicago, 1902); The records of the city of Norwich, $i$, ed. Rev. William Hudson and John Cottingham Tingey (Norwich and London, 1906). The few surviving municipal ordinances from English towns and cities that deal with apparel focus on the attire of women: Baldwin, "Sumptuary legislation", 198-200, 213; Frank Rexroth, Deviance and power in late medieval London, trans. Pamela E. Selwyn (Cambridge, 2007), 96-101.

${ }^{x c v i}$ This is similar to the situation of townspeople in the lands of French kings, where the crown and city governments passed overlapping sumptuary regulations: Johanna Moyer, "Sumptuary law in ancient regime France, 1229-1806”, unpublished Ph.D thesis, Syracuse University (1997), xi-xii, xvi-xvii.

xcvii Anc. rec. Dublin, i, 326.

xcviii Anc. Rec. Dublin, i, 326.

xcix The yellow shirt and shaggy woollen mantle appear in a watercolour painting of Lucas de Heere from about 1570, reproduced in McClintock, Old Irish and Highland dress, frontispiece. 'Lennox Barrow, "Riding the franchises", Dublin Historical Record 33:4 (1980), 135-8; Anc. Rec. Dublin, 2, 156-8, 190-8.

ci Baldwin, “Sumptuary legislation”, 133.

cii Samuel Johnson and George Steevens (eds), The Plays of William Shakespeare in ten volumes (10 vols, London, 1778), iv, 123.

ciii Stat. Ire., Hen. VI, 54-109; Arthur Sherbo has highlighted Steeven's painstaking research on rare sources, so it is possible that he found records that are no longer extant: Arthur Sherbo, “George Steevens”, ODNB. No 1446 parliament appears in Richardson and Sayles' list of Irish parliaments and councils, but a parliament was convened at Trim in early 1477 , on January $13^{\text {th }}$. 
This was in the twenty-fifth regnal year of Henry IV, which spanned 1446 and 1447, so it would be possible to mistake the year: Richardson and Sayles, The Irish parliament, 355; "Patent Roll 25 Henry VI”, nos 10-12, “Close Roll 25 Henry VI”, nos 3-4, CIRCLE.

${ }^{\text {civ }}$ For the increasing unpopularity of yellow, see Michel Pastoureau, "Formes et couleurs du désordre: le jaune avec le vert”, Médiévales 4 (1983), 62-73; John Munro, “The Anti-red shift - to the dark side: colour changes in Flemish luxury woolens, 1300-1500", Clothing and textiles 3 (Woodbridge, 2007), 55-96, at 89-90; Ann Rosalind Jones and Peter Stallybrass, "Yellow starch: fabrications of the Jacobean court" in Jones and Stallybrass (eds), Renaissance clothing and the materials of memory (Cambridge, 2000), 63, 74-5.

${ }^{c v}$ Saffron shirts were associated with women in 1466, but De Heere and other, later artists and commentators do not agree on the gender associations of saffron shirts. They were probably worn by both men and women: Hiram Morgan, "Festive Irishmen: an "Irish" procession in Stuttgart 1617”, History Ireland 3:5 (1997), 14-20, at 15; Susan Bracken, “Lucas de Heere”, ODNB; Margaret Rose Jaster, "Breeding dissoluteness and disobedience: clothing laws as Tudor colonialist discourse", Critical Survey, 13:3 (2001), 61-77, at 62; Chieracati, "Francesco Chieracati's letter", 9.

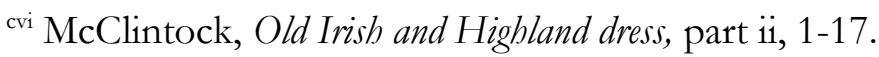

cvii Mairead Dunlevy, Dress in Ireland (London, 1989), 47; Mary Purcell, “St Patrick's purgatory: Francesco Chieracati's letter to Isabella d'Este", Seanchas Ardmbacha 12:2 (1987), 1-10, at 9; Vital, Archduke Ferdinand's visit, 284-6; Hiram Morgan, "Sunday 6 June 1518 - the day the Renaissance came to Ireland", History Ireland 20:3 (2012), 18-21; Richard Stanihurst, De Rebus in Hibernia Gestis, eds John Barry and Hiram Morgan (Cork, 2013), 12; Fynes Moryson, “The manners and customs of Ireland”, 223, 321; D.B. Quinn (ed.), “The Bills and statutes of the Irish parliaments of Henry VII and Henry VIII", Analecta Hibernica 10 (1941), 71-169, at 141.

cviii Moryson, "Description of Ireland", 227, CELT. Saffron was certainly known and used in Ireland, but there are a number of native plants that can give a strong yellow dye: Lillias Mitchell 
(ed.), Irish spinning, dyeing and weaving: an anthology from original documents (Dundalk, 1978), 22-3; Brid Mahon, "Traditional dyestuffs in Ireland" in Gold under the furze: Studies in folk tradition, eds Alan Gailey and Dáithí Ó hÓgáin (Dublin, 1982), 115-28, at 118-19.

cix Edward Thompson, "Fynes Moryson", ODNB. For New English views of the Irish and the English of Ireland, see Thomas Herron, Spenser's Irish work: poetry, plantation and colonial reformation (Aldershot, 2007); Nicholas Canny, "Identity formation in Ireland: the emergence of the AngloIrish" in Colonial identity in the Atlantic world 1500-1800, eds Nicholas Canny and Anthony Pagden (Princeton, 1987), 159-212; Colm Lennon, "Richard Stanihurst (1547-1618): Old English identity", Irish Historical Studies 21:82 (1978), 121-43.

${ }^{c x}$ At least one woman from an elite colonial family was making these shirts by the 1530s: Joan, daughter of James Butler, eighth lord of Dunboyne, and wife of Roland Eustace of Mullaghcash (southern co. Kildare), who became second Viscount Baltinglass in 1549: State Papers, Hen. VIII, iii, no. 3, 140; Eustace Ticknell, “The Eustace family and their lands in county Kildare”, Journal of the Kildare Archaeological Society 13:6 (1955), 270-87, at 283. A licence was given in 1410 to the prioress of the abbey of St Mary in Graney on the Kildare marches to give and sell "English and Irish clothing", which indicates that nuns in this religious house of the colony were producing, or at least trading in, Irish clothing - perhaps even saffron shirts - by the early fifteenth century:

"Patent Roll 11 Henry IV”, no. 82, CIRCLE.

cxi Katharine Simms, "Bards and barons" in Robert Bartlett and Angus MacKay (eds), Medieval frontier societies (1989), 177-97.

cxii State Papers, Hen. VIII, iii, no. 3, 139, 140.

cxiii State Papers, Hen. VIII, iii no. 2, 450.

cxiv See legislation of 1537 discussed below, 30-1. Commentators like Spenser also made explicit links between Irish attire and disloyalty/rebellion: View of the present state of Ireland, CELT.

${ }^{c x v}$ This shift is best explained by the changing source material rather than marking a real change in attitudes since dress and appearance were increasingly reduced to secondary, rather than a 
fundamental, requirements of "Englishness" or "Irishness" from the fifteenth century onwards: See Booker, Cultural exchange and identity, chapts. 6 and 8; Robert Bartlett, "Medieval and modern concepts of race and ethnicity", Journal of Medieval and Early Modern Studies 31:1 (2001), 39-56.

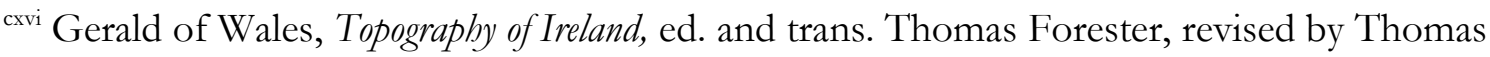
Wright (Cambridge, Ontario, 2000), 101; Benjamin Hudson, “The Changing economy of the Irish sea province AD 900-1300” in Brendan Smith (ed.), Britain and Ireland 900-1300: insular responses to medieval European change (Cambridge, 1999), 39-66, at 53; Timothy O’Neill, Merchants and mariners in medieval Ireland (Dublin, 1987), 66-9.

cxvii Statute rolls of the Irish parliament Richard III to Henry VIII, ed. Philomena Connolly (Dublin, 2002) [Stat. Ire. Rich. III-Hen. VIII], 236-44.

cxviii Jaster, "Breeding dissoluteness", 77, note 32; Calendar of State Papers relating to Ireland, 15091573, ed. H. C. Hamilton, et al., 23 vols (London, 1860-1903), i, 359, 413; Thomas Lee, “The Discovery and Recovery of Ireland with the Author's Apology (1599/1600)", transcribed by John McGurk from BL Add MS 33743, Folio 86, CELT.

cxix Vital, Archduke Ferdinand's visit, 288; PRO 63/57/144 II, “Herbert on Mantles” [Hap Hazard, Ceres Online Publication Interactive (COPIA), http://www.english.cam.ac.uk/ceres/haphazard/]; Christopher Maginn, "Sir William Herbert (c.1553-1593)", ODNB.

cxx Fynes Moryson, "The commonwealth of Ireland”, 261, CELT; Spenser, View of the present state of Ireland, CELT. Although the View was not printed until 1633, it "circulated widely in manuscript form" after c.1596 and the close wording of Moryson and Spenser's comments on the mantle suggests that Moryson had read it when he was writing his "commonwealth" in the early sixteenth century: Andrew Hadfield, "Another case of censorship? The riddle of Edmund Spenser's “A view of the present state of Ireland”, History Ireland 2:4 (1996), 26-30, at 27. ${ }^{\text {cxxi }}$ Ibid. Vital mentioned this long fringe in 1518: Vital, Archduke Ferdinand's visit, 288. 
cxxii An act against the wearing of visors and "disguised persons" from England in 1511 makes this link particularly clear, but also suggests links between disorder and entertainers, ones that are echoed in some of the Irish statutes regulating the movements of bardic poets: Statutes at Large, vol. iii, 12; Claire Sponsler, "Outlaw masculinities: Drag, blackface, and late medieval labouringclass festivities" in Jeffrey Jerome Cohen and Bonnie Wheeler (eds), Becoming Male in the Middle Ages (New York, 1997), 321-47, at 327-9.

cxxiii Valentin Groebner, Who are you? Identification, Deception and Surveillance in Early Modern Europe (New York, 2007), 82.

cxxiv John Ziegler, "Irish mantles, English nationalism: Apparel and national identity in early modern English and Irish texts", Journal for Early Modern Cultural Studies 13:1 (2013), 73-95, at 77, 84. For this link between the mantle and freedom of action, see Jaster, "Breeding Dissoluteness", 61.

${ }^{\mathrm{cxxv}}$ J.T. Gilbert, "Municipal Archives in Waterford" and "Statute Book of the town of Galway 1485-1710" in 10 report of Historical Manuscript Commission, Appendix V (London, 1885), 307-8. For grants of English law and the legal status of the Irish, see A. J. Otway-Ruthven, "The native Irish and English law in medieval Ireland”, Irish Historical Studies 7:25 (1950), 1-16, at 7, 10; Frame, "Les Engleys", 85-90; Robin Frame, "Ireland after 1169: barriers to acculturation on an 'English' edge” in Keith Stringer and Andrew Jotischky (eds), Norman Expansion: Connections, Continuities, and Contrasts (Farnham, 2013), 115-41, at 119-123.

cxxvi Statute Rolls of the Parliament of Ireland: King Edward the Fourth, ed. Henry F. Berry, vol. i (Dublin, 1914), 291 [Stat. Ire., 1-12 Edw. IV].

cxxvii Gilbert, "Municipal Archives in Waterford", 312-3.

cxxviii Foreign had a broad meaning in this period and could include anyone who was not from the locality or administrative unit. In urban contexts, it often meant either non-citizens or anyone who did not reside in the city: "foreign", adj. and n., OED online (Oxford, 2014) [www.oed.com]. 
cxxix Gilbert, "Statute Book of Galway", 400.

${ }^{c x x x}$ Irish men who received English law in the fourteenth century were sometimes forced to abandon their Irish clothing and hairstyles, and Irishmen who submitted to Henry VIII also pledged to wear English attire. It is possible that gifts of cloth and a gold collar sent to Énri Ó Néill by Edward IV in 1463 were intended to encourage him to dress in an English manner, as well as to win his support: Frame, "Les Engleys nées en Irlande", 95; S.P., Hen. VIII, iii, no. 3, 266, 320; Annals of Ulster, 1463.

${ }^{\text {cxxi }}$ The complexity and fluidity of medieval identity has been increasingly recognized: Bartlett, "Medieval and modern concepts", 39-56.

cxxxii Nirenberg, "Conversion, sex, and segregation", 1065-93; Benjamin Ravid, "From Yellow to red: on the distinguishing head-covering of the Jews of Venice", Jewish History 6 (1992), 179-210, at 179; Hughes, "Distinguishing signs", 3-59.

cxxxiii Alexandra Guerson, "Seeking remission: Jewish conversion in the Crown of Aragon, $c$. 1378-1391", Jewish History 24 (2010), 38-44.

${ }^{\text {cxxxiv }}$ Booker, Cultural exchange and identity, chapt. 8. For the rise of proto-racial thought in Ireland and across Europe, see also Richard C. Hoffman, "Outsiders by birth and blood: racist ideologies and realities around the periphery of medieval European culture", Studies in Medieval and Renaissance History 6 (1983), 1-36, esp. 5-7, 21-2; Bartlett, The making of Europe, 236-42; Peter Biller, "Proto-racial thought in medieval science" in Miriam Eliav-Feldon, Benjamin Isaac, and Joseph Ziegler (eds), The Origins of racism in the West (Cambridge, 2009), 157-80; Charles de Miramon, "Noble dogs, noble blood: the invention of the concept of race in the late Middle Ages" in Eliav-Feldon, Isaac, and Ziegler, Origins of racism, 200-16.

${ }^{\text {cxxxv }}$ Quinn, "Bills and statutes", 92-3; Statutes at Large, Ireland, i, 52-3. See Ellis, Ireland in the age of the Tudors, 90-4.

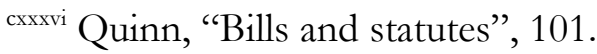


${ }^{\text {cxxxvii }}$ A letter from Stephen ap Parry, a Welshman who travelled in the retinue of deputy Leonard Grey, to Henry VIII in 1536 makes clear the link in his mind between the appropriate civic dress and the Englishness of Cork's mayor and aldermen: S.P. Hen. VIII, iii, no. 2, 281-4. cxxxviii Quinn, "Bills and statutes”, 97; Gilbert, "Statute Book of Galway”, 396; Ruth Frost, “The urban elite" in Carole Rawcliffe and Richard Wilson (eds), Medieval Norwich (Hambleton, 2004), $235-54$, at 36.

cxxix The Pale was a late fifteenth-century term used to describe the fortified core of the colony that stretched from near Dundalk in the north to the south of county Dublin: Steven Ellis, "The English Pale: A failed entity?”, History Ireland 19:2 (2011), 14-17; Sparky Booker, "Irish clergy and the diocesan church in the "four obedient shires", Irish Historical Studies 39:154 (2014), 179-209, at $179-83$.

cxl Italics mine: Quinn, “Bills and statutes”, 96, 101.

cxli Stat. Ire., John- Hen. V, 435; State Papers, Hen. VIII, iii, no. 2, 216. Gerald of Wales commented upon the Irish habit of riding without a saddle in the twelfth century: Gerald of Wales, Topography of Ireland, 69.

cxlii Richard Cowley claimed in 1537 that English marchers must not be made to ride in saddles immediately, since they were better at fighting without them and their efforts were needed to combat the Irish: State Papers, Hen. VIII, iii no. 2, 449-50. The influence of the stirrup on medieval warfare has been debated, but they were clearly not militarily essential in the Irish context: B. Bachrach, "Charles Martel, mounted shock combat, the stirrup, and feudalism" in J. France and K. DeVries (eds), Warfare in the Dark Ages (Aldershot, 2008), 221-47. cxliii Quinn, "Bills and statutes", 96.

cxliv There were other examples of moves to lessen trade and commerce with the Irish and the importation of bows from England was encouraged: Stat. Ire., Hen. VI, 45; Statute Rolls of the Parliament of Ireland: King Edward the Fourth, ed. J. Morrissey, vol. ii (Dublin, 1939), 99-101, 819-21 
[Stat. Ire., 12-22 Edw. IV]; Calendar of Inquisitions formerly in the Office of the Chief Remembrancer of the Exchequer, ed. M. Griffith (Dublin, 1991), 20-45.

cxlv Stat. Ire., Hen. VI, 649; Stat. Ire., 1-12 Edw. IV, 293, 715-19; Agnes Conway, Henry VII's relations with Scotland and Ireland, 1485-1498 (New York, 1972), 123, 4; State Papers, Hen. VIII, iii, no. 2, 12; F.P. Magoun, "Football in medieval England and in middle-English literature", The American Historical Review 25:1 (1929), 33-45, at 38, 42, 45; F.P. Magoun, "Scottish popular football, 1424-1815”, The American Historical Review 37:1 (1931), 1-13, at 1-2.

cxlvi John Bradley (ed.), Treasures of Kilkenny: Charters and civic records of Kilkenny city (Kilkenny, 2003), 22.

cxlvii Clodagh Tait, "Safely delivered: childbirth, wet-nursing, gossip-feasts and churching in Ireland, c. 1530-1690”, Irish Economic \& Social History 30 (2003), 1-23, at 18.

cxlviii Bradley, Treasures of Kilkenny, 24, 40.

cxlix Phillips, "Masculinities and sumptuary laws", 28. This has parallels in Roman sumptuary law, as Killerby notes: Sumptuary Law in Italy, 17.

${ }^{\mathrm{cl}}$ John Martin Vincent, Costume and conduct in the laws of Basel, Bern, and Zurich 1370-1800 (Baltimore, 1935), 21-3.

cli Killerby, Sumptuary Law in Italy, 39, 70-4; Vincent, Costume and conduct, 25-41; Kent Roberts Greenfield, Sumptuary Law in Nürnberg: A Study in Paternal Government, Johns Hopkins Studies in Historical and Political Sciences (Baltimore, 1918), 32-45; Bulst, "Zum problem”, 43, 45; Bulst, "Vom Luxusverbot zur Luxussteuer", 54-5; Shaw, "Sumptuary legislation in Scotland", 91-2; Widmayer, “The sumptuary laws of MC Montpellier H119”, 138-40. clii Anc. rec. Dublin, i, 31. For keening see Gerald of Wales, Topography of Ireland, 72-2; "The Irish funeral cry (the Ullaloo, keeners and keening at Irish funerals)", The Dublin Penny Journal 1:31 (1833), 242-4. Killerby argued that funerals were regulated because they were venues for the expression of factional rivalry and subversion of the authorities, but this makes more sense in the context of Italian city states: Kovesi Killerby, Sumptuary law in Italy, 72. 
cliii See note 82.

${ }^{\text {cliv }}$ Charles Coulson, Castles in medieval society: fortresses in England, France and Ireland in the central Middle Ages (Oxford, 2003), 109; "Richard II: January 1390", "Henry V: October 1419”, and “Original Documents: Edward I Parliaments, Roll 12”, Parliament Rolls of Medieval England, ed. Chris Given-Wilson, Paul Brand, Seymour Phillips, Mark Ormrod, Geoffrey Martin, Anne Curry and Rosemary Horrox (Woodbridge, 2005), https://www.british-history.ac.uk/noseries/parliament-rolls-medieval [accessed 15 December 2014].

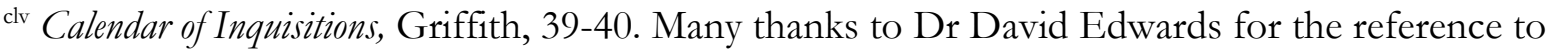
Neale: Ferguson MSS, "Repertory to the memoranda rolls of the Exchequer, Edward VIElizabeth I", National Library Ireland, 173.

clvi Steven Ellis, "Thomas Cromwell and Ireland, 1532-1540”, The Historical Journal 23:3 (1980), 497-519, at 502-4.

clvii State Papers of Henry VIII, 11 vols (London, 1830-52), iii, no. 2, 218 [State Papers, Hen. VIII]. clviii Gerald of Wales, Topography of Ireland, 69.

clix State Papers, Hen. VIII, iii, no. 2, 216.

clx State Papers, Hen. VIII, iii, no. 2, 215.

clxi State Papers, Hen. VIII, ii, 309-11.

clxii State Papers, Hen. VIII, ii, 310.

clxiii Uscar in Irish means an ornament or jewel, so this ban presumably refers to garments with jewels sewn onto them: Compact dictionary of the Irish language (Dublin, 1998), 630.

ckiv Stat. Ire., RIII-Hen. VIII, 236-44. Justice Luttrell revisited many of these issues the following year in his "Book": State Papers, Hen. VIII, iii, no. 2, 508.

${ }^{c k x}$ Even before surrender and regrant was formally instituted in the 1540s, Henry VIII considered the Irish his subjects: Ellis, Ireland in the age of the Tudors, 122-4. The success and implications of the policy of surrender and regrant are debatable: Christopher Maginn, 
"Surrender and Regrant" in the historiography of sixteenth-century Ireland", The Sixteenth Century Journal 38:4 (2007), 955-74.

clxvi Quinn, "Bills and statutes", 141; S.P. Hen. VIII, iii, no. 2, 281-4, 449, 482-4.

clxvii Cal. Carew MSS, i, 180-2; S.P. Hen. VIII, iii, no. 3, 304-5.

clxviii Kerns (Irish foot-soldiers) and galloglasses (heavily armoured Scottish soldiers) comprised the majority in military forces in the colony: Katharine Simms, From kings to warlords: the changing political structure of Gaelic Ireland in the later Middle Ages (Woodbridge, 1987), 172; K.W. Nicholls, "Scottish mercenary kindreds in Ireland 1250-1600" in Seán Duffy (ed.), The world of the galloglass: kings, warlords, and warriors in Ireland and Scotland, 1200-1600 (Dublin, 2007), 86-105.

clxix There had always been Englishmen from England in the colony, and many colonists were educated in England, but English influence and the drive to centralize grew in Henry VIII's reign and chief governors from England were employed in the wake of the Kildare rebellion. For example, Anthony St Leger was lord deputy in 1541, and he seems to have had a significant influence on these 1541 enactments. He had previously served as a justice of the peace, with responsibility for enforcing sumptuary law, so he may have had a particularly good knowledge of it: Baldwin, "Sumptuary legislation”, 124-5, 131-2, 139, 142, 200, 214; Alan Bryson, "Anthony St Leger", $O D N B$.

clxx Steven Ellis has tracked the resurgence of the Irish economy: Steven Ellis, "Region and frontier in the English state: the English far north, 1296-1603" in Steven Ellis and Raingard Eßer with Jean-François Berdah and Miloš Řeznik (eds), Frontiers, regions and identities in Europe (Pisa, 2009), 63-4; Ellis, “The English Pale: A failed entity?”, 14-17.

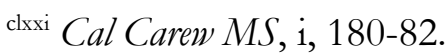

clxxii Hunt, Governance of the consuming passions, 29, 34.

clxxii Baldwin, "Sumptuary legislation", 133. This link between urban areas and sumptuary law has long been recognized, and many surveys of law focus specifically on cities and civic legislation: Vincent, Costume and conduct, Philippa Jackson, "Parading in public: patrician women and 
sumptuary law in Renaissance Siena", Urban History $37: 3$ (2010), 452-63; Herman Freudenberger, "Fashion, sumptuary laws, and business", The Business History Review 37:1/2, (1963), 39-40; Hunt, Governance of the consuming passions, 108-9.

${ }^{\text {clxxiv }}$ Rexroth, Deviance and power, 96-101.

${ }^{\text {clxxv }}$ Much of the Irish material makes no comment on the gender associations of the styles it discusses or include both men and women equally in prohibitions, like this civic ordinance from Kilkenny's Irishtown in 1565: “Corporation book of Irishtown”, ed. John Ainsworth, Analecta Hibernica 28 (1978), 1, 3-78, at 27.

clxxvi Shaw, "Sumptuary legislation in Scotland", 89-90; Heller, "Limiting Yardage", 127; Owen Hughes, "Regulating women’s fashion”, 136-58; Kathryn Reyerson, "Medieval silks in Montpellier: the silk market ca. 1250-ca. 1350”, Journal of European Economic History 11 (1982), 117-40, at 118 n. 2; Jackson, "Parading in public", 452-63; Killerby, Sumptuary Law in Italy, 12001500, 39. Each of the northern Italian cities whose ordinances appear in Muzzarelli's collection include material regulating women, generally far more often than men: La legislazione suntuaria, passim.

clxxvii Phillips, "Masculinities and sumptuary laws", 23-4; Muzzarelli, "Reconciling the privilege", 606. John Scattergood noted that women's dress was also less an object of satire than men's in England: Scattergood, "Fashion and morality in the late Middle Ages", 252.

clxxviii Phillips, "Masculinities and sumptuary laws", 27-8.

clxxix Phillips, "Masculinities and sumptuary laws", 31-2.

${ }^{\text {clxxx }}$ Historians of medieval women have emphasized their "soft" political power, exercised through familial and personal connections and networks of patronage, although this picture has been complicated considerably in recent decades as the consensus has grown that many women also exercised "hard" power. Furthermore, the very distinctions between soft and hard power and public and private spheres have been increasingly challenged. Nevertheless, the lack of access to avenues of patronage of the type that centred around a royal court and the emphasis on 
military service in the colony may have lessened women's political influence in English Ireland, relative to England, even though the English common laws that prevailed in the colony ensured that women in both jurisdictions had the same legal entitlements: Mary Erler and Maryanne Kowaleski (eds), Women and power in the Middle Ages (Athens, GA, 1988); Heather Tanner (ed), Medieval elite women and the exercise of power, 1100-1400 (London, 2019), esp. introduction. clxxxi The pattern in the sumptuary law, with Scotland's attitude towards female fashion echoing southern European attitudes, for example, disrupts the influential but increasingly challenged theory of a "North-South" divide in medieval Europe, which posits greater legal rights, greater access to family property and a later age of marriage for women in general in Northern Europe: Jennifer Ward, Women in medieval Europe, 1200-1500 (London, 2002), 6-7, 11, 28-29, 40. Hughes has suggested that, in Italy, the greater the church's involvement with sumptuary law, the more restrictive the regulations were of women's dress, while Wilson draws a possible link between the power of municipal governments - at their height in Italy in this period - and a greater focus on women's attire. These point the way towards possible avenues of enquiry for the colony in Ireland: Hughes, "Sumptuary law and social relations", 134, 137-8; Wilson, "Common threads", 148.

clxxxii Most Irish witch trials were concerned with female witches, but witch trials overall were comparatively uncommon in Ireland: those that did occur were usually instigated by newcomers to the island. Andrew Sneddon explained the paucity of prosecutions with reference to the majority Irish Catholic population's reluctance to make accusations of witchcraft in the early modern period, while Maeve Callan suggests that the relative decentralization of the Irish church and its openness to diversity of belief ensured that there were few medieval heresy or witchcraft accusations. Both arguments are reasonable, but attitudes towards female behavior may also have played some role: Andrew Sneddon, "Witchcraft belief and trials in early modern Ireland", Irish Economic and Social History, 39 (2012), 1-25, at 24-5; Maeve Callan, The templars, the witch and the wild Irish: vengeance and heresy in medieval Ireland (Dublin, 2015), 235-8. The material that survives from 
ecclesiastical and municipal courts in Ireland is patchy, but records of the consistory court of Armagh and visitation records of the archbishop of Armagh record ex officio cases, and none regarding scolds are extant from the late fourteenth, fifteenth or early sixteenth centuries, when this charge was fairly common in the English context. A case of a woman accused in 1448 of abusive language in Kilkenny bears some resemblance to scolding cases, but the term scold is not used and the woman in question was pardoned: Liber Primus Kilkenniensis, 64; Sandy Bardsley, Venomous Tongues: Speech and gender in late medieval England (Philadelphia, 2006), 106-8.

clxxxiii The historiography of witchcraft and gender is immense, but for an introduction to this historiography, particularly in England, see Karen Jones and Michael Zell, "The divels speciall instruments': women and witchcraft before the 'great witch-hunt', Social History 30:1 (2005), 4563, at 45-9, 62-3. For Scotland, see Julian Goodare, "Women and the witch-hunt in Scotland", Social History 23:3 (1998), 288-308. For gender and scolding, see Bardsley, Venemous Tongues, chapts. 5-7, especially 146-152; Garthine Walker, Crime, gender and social order in early modern England (Cambridge, 2003), 99-106.

${ }^{\text {clxxxiv }}$ For women and medieval witch trials outside the British Isles see Susanna Burghartz, "The equation of women and witches: a case study of witchcraft trials in Lucerne and Lausanne in the fifteenth and sixteenth centuries" in Richard Evans (ed.), The German underworld: deviants and outcasts in German history (London, 1988), 57-74.

clxxxv Phillips, "Masculinities and sumptuary laws", 27; Rexroth, Deviance and power, 100, 178-9, 173; Brundage, "Sumptuary law and prostitution in late medieval Italy"; Muzzarelli, La legislarione suntuaria, 47-8; Shaw, "Sumptuary legislation in Scotland", 89-90; Heller, "Limiting Yardage", 126; Stella Mary Newton, Fashion in the age of the Black Prince, a study of the years 1340-1365 (Woodbridge, 1980), 132. clxxxvi Killerby, Sumptuary Law in Italy, 62; Phillips, "Masculinities and sumptuary laws", 26; Greenfield, "Sumptuary law in Nürnberg", 115-16; Gerhard Jaritz, "Ira Dei, material culture, and 
behavior in the late Middle Ages: evidence from German-speaking Europe”, Essays in Medieval Studies 18 (2001), 53-66, at 56.

clxxxvii Ecclesiastical authorities in Ireland did regulate clerical dress, like the anti-beard ordinances of the archbishop of Armagh, which related to notions of what was sufficiently humble appearance for a cleric: Booker, "Irish clergy and the diocesan church", 193-4. For the medieval semiotics of clerical beards, see Gábor Klaniczay, "Fashionable beards and heretic rags" in Klaniczay, trans. Susan Singerman, ed. Karen Margolis, The uses of supernatural power: the transformation of popular religion in medieval and early modern Europe (Princeton, 1990), 51-78. clxxxviii Thomas Izbicki, "Forbidden colors in clerical dress" in Robin Netherton and Gale OwenCrocker (eds), Medieval clothing and textiles 1 (Woodbridge, 2005), 105-14; Lachaud, "Dress and social status”, 108-11; Camilla Luise Dahl, "Mengiad klathe and tweskifte kladher: Marbled, patterned and parti-coloured clothing in medieval Scandinavia" in The medieval broadcloth: changing trends in fashions, manufacturing and consumption, eds Kathrine Vestergard Pedersen and Marie-Louise Nosch (Oxford, 2009), 122-38, at 129-32. See the thoughts on clerical dress of the fifteenthcentury author John Mirk, Instructions for Parish Priests, ed. Edward Peacock (London: Early English Text Society, 31, 1868), 2; G. R. Owst, Literature and pulpit in medieval England (Oxford, 1961), 404-11.

clxxix This neglect is due in large part to the intractable source material, although there remains more to be done with bardic poetry commissioned by the English of Ireland and with HibernoEnglish literature.

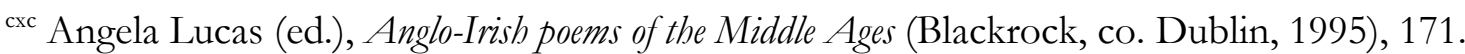
cxci St John Seymour, "Three medieval poems from Kilkenny", Proceedings of the Royal Irish Academy 41c (1932-4), 205-09, at 209. cxcii Jaster, "Breeding Dissoluteness", 77, n. 34. cxciii See 28-9 above. Feasts were the subject of some of the earliest English sumptuary laws, as well as Scottish and English sixteenth-century laws: Wilfred Hooper, "The Tudor sumptuary 
laws", The English Historical Review 30:119 (1915), 433-49, at 435; Baldwin, "Sumptuary legislation", 17-18; Kovesi Killerby, Sumptuary law in Italy, 68; Shaw, "Sumptuary legislation in Scotland", 90-3.

cxciv The earliest clearly protectionist law I have found from Ireland was an ordinance of the Waterford city council from 1599, which claimed that the city was impoverished because men dressed their servants in imported textiles rather than those produced in the city or colony: Gilbert, "Municipal Archives in Waterford", 336.

cxcv Baldwin, "Sumptuary legislation”, 133, 303-4; Rexroth, Deviance and power, 172-9; Shaw, "Sumptuary law in Scotland”, 93-95; Killerby, Sumptuary Law in Italy, 46-7, 134-42.

${ }^{\text {cxcri }}$ Concerns about the Irish spying were expressed in a number of administrative sources from the colony: Stat. Ire., John-Hen. V, 412; Stat. Ire., Hen. VI, 45.

cxcvii See Booker, Cultural exchange and identity, chaps. 2, 3.

cxcviii See n. 150 above. Henry VIII intermittently invested in Ireland and appointed chief governors from England even before the fall of the Kildares in 1534, but after this and through the sixteenth century, crown involvement in Ireland and the program of plantation continued apace: Ellis, Ireland in the age of the Tudors, 119-121, 131-4, 243-311.

cxcix Such material from some of these areas has been discussed already, but for France, Germany and the Low Countries see Frederik Buylaert, Wim De Clercq and Jan Dumolyn, "Sumptuary legislation, material culture and the semiotics of "vivre noblement" in the county of Flanders (14th-16th centuries)", Social History 36:4 (2011), 393-417, at 401-2; E. Jane Burns, Courtly love undressed: reading though clothes in medieval French culture (Philadelphia, 2002), 33; Gerhard Jaritz, "Social grouping and the languages of dress in the late Middle Ages", The Medieval History Journal 3/2 (2000), 236-59, at 247; Hughes, "Sumptuary law and social relations", 128.

${ }^{c c}$ The golden bridles act of 1447 included an exemption for bishops and knights of a certain income, for example.

cci Ellis, "Thomas Cromwell and Ireland", 497-519. 
${ }^{\text {ccii }}$ For a discussion of the historiography see Booker, Cultural exchange and identity, 3-8.

cciii See above, 21-3; Booker, Cultural exchange and identity, 61-4.

cciv See above, n. 113.

${ }^{\text {ccv }}$ Distinctions between long-resident Irish inhabitants of the colony and newer arrivals are discussed in Booker, Cultural exchange and identity, chapt. 3.

${ }^{\text {ccvi }}$ For growing anxiety about the Irish in the colony see Ibid; Watt, "The Anglo-Irish colony under strain”, 352-96.

${ }^{\text {ccvii }}$ Many thanks to Professor Robin Frame and Dr Len Scales for their comments and suggestions about possible reasons for the paucity of sumptuary law that dictated dress for different ethnicities in Wales and Germany respectively. For the distinct dress of the Welsh: Davies, "The peoples of Britain and Ireland 1100-1400", 14-15. Dr Scales indicates that fourteenth-century manuscripts of the Sachsenspiegel contain imagines of Slavic people in distinct dress, and the late fourteenth-century "De Theutonicis bonum dictamen", to which he and Robert Bartlett ascribe a Czech, urban provenance, also describes differences in German and Slavic hairstyles and clothes: Len Scales, The Shaping of German identity: authority and crisis, 1245 1414 (Cambridge, 2012), 387-89; Bartlett, Making of Europe, 236-7.

ccviii Frame has highlighted the ways in which the later date of conquest in Ireland than Wales influenced its law, administration and society: Robin Frame, "Lordship and liberties in Ireland and Wales, c. 1170-1360" in Huw Pryce and John Watts (eds), Power and identity in the Middle Ages: essays in memory of Rees Davies (Oxford, 2007), 125-38, at 126-7, 137-8; Max Lieberman, The march of Wales, 1067-3012: a borderland of medieval Britain (Cardiff, 2008), 100-01.

${ }^{\text {ccix }}$ K. W. Nicholls, Gaelic and Gaelicised Ireland in the Middle Ages, $2^{\text {nd }}$ edn (Dublin, 2003); Davies, Age of Conquest, 283-4, 443-58; Ralph Griffiths, “After Glyn Dwr: an age of reconciliation?”, Proceedings of the British Academy 117 (2002), 139-64.

ccx Davies, Age of Conquest, 396-7, 414. 
ccxi Scales, Shaping of German identity, 410-15. Bohemia, for example, was settled peacefully: Len Scales, "At the margin of community: Germans in pre-Hussite Bohemia", Transactions of the Royal Historical Society 9 (1999), 332.

${ }^{\text {ccxii }}$ Scales emphasizes the diversity of German settlement in the east as well as the differences in the impact that this settlement had on native populations: Scales, Shaping of German identity, 398403.

ccxiii See above, 8 . The attire of lepers and prostitutes was regulated in medieval Hungary alongside that of Jews, Muslims, and a religious group called Cumans: Berend, "Non-Christian clothing in Hungary", 173.

${ }^{\text {ccxiv }}$ Steven Ellis, "Region and frontier in the English state: Co. Meath and the English pale, 14601542" in The borders of Europe: hegemony, aesthetics and border poetics, eds Helge Vidar Holm, Sissel Laegred, and Torgeir Skorgen (Aarhus, 2012), 63-4. Trade with Bristol, for example, brought luxury items, but these increased significantly in the first decades of the sixteenth century and were less diverse before this point: Susan Flavin and Evan T. Jones, Bristol's trade with Ireland and the continent, 1503-1601 (Dublin, 2009), xvii-xviii.

ccxv Brundage, "Sumptuary laws and prostitution in late medieval Italy", 352-3. Populations fluctuated over the period discussed here. A reasonable estimate for Dublin, the largest Irish city in this period, would be between 8,000 and 11,000, with higher end of this range before the Black Death: Howard Clarke (ed.), "Dublin, part one to 1610", Irish Historic Towns Atlas (Dublin, 2002), 12. This places it in the lowest or second lowest tier (of 5) for cities in Europe c.1300, as mapped by Rudolf Cesaretti, et al, "Population-area relationship for medieval European cities", PLOS One 11:10 (2016), Fig. 2. No Irish city makes it onto Bairoch, et al.'s map of European cities with a population over 12,000 c. 1500: Paul Bairoch, et al, La population des villes européennes de 800 á 1850 (Geneva, 1988), 236

ccxvi Ireland was poorer than England, Scotland and Wales in 1290, and although comparison is difficult, the value of benefices suggests that it never caught up. The returns of the Irish 
exchequer and the frequent mentions of "waste" lands in land documentation add to the picture of economic woe: Steven Ellis, "Economic problems of the church: why the Reformation failed in Ireland", The Journal of Ecclesiastical History 41 (1990), 239-65, at 248-57; Bruce Campbell, "Benchmarking medieval economic development: England, Wales, Scotland and Ireland, c. 1290”, Economic History Review 61:4 (2008), 896-945, at 902; Kelly, Black Death in Ireland, 91. ccxvii State Papers Henry VIII, iii, no. 3, 289. A letter of Richard III from 1484 requested that the $9^{\text {th }}$ earl wear "our English habite and clothing" and sent a gold collar and a large quantity of luxurious apparel "for [his] persone of thenglish fassion" for him. This may suggest that Richard, at least, was concerned that financial restraints were holding Desmond back from dressing in a manner appropriate for an English earl: Letters and Papers Illustrative of the Reigns of Richard III and Henry VII, ed. James Gairdner, i (London, 1861), 73; David Beresford, “James fitz Thomas FitzGerald, 9th earl of Desmond" and Terry Clavin, "James fitz John FitzGerald, $14^{\text {th }}$ earl of Desmond" in DIB.

ccxviii Shaw, "Sumptuary legislation of Scotland", 103, 111.

ccxix Freudenberger, "Fashion, sumptuary laws, and business", 39-40; Heller, "Anxiety, hierarchy and appearance”, 312; David Brégaint, Vox Regis: Royal communication in high medieval Norway (Leiden, 2016), 202.

${ }^{c c x x}$ For the households and affinities of Ormond and Kildare see David Edwards, The Ormond lordship in county Kilkenny, 1515-1642: the rise and fall of Butler feudal power (Dublin, 2003), 16-17; Ellis, Tudor frontiers, 129-41.

${ }^{c c x x i}$ Ellis, Ireland in the age of the Tudors, 35; Manred (manrent), n, "the men who could be called upon by a lord for military service”, OED [online edition, 25/06/15]. ccxxii These private forces were necessary both to combat Irish threats and to prosecute factional disputes within the colony and they could be sizeable: Ellis, Tudor frontiers, 128-9; Peter Crooks, "Factions, feuds and noble power in the lordship of Ireland, c. 1356-1496", Irish Historical Studies $35: 140$ (2007), 425-54, at 425-30, 437-40, 450-1. 
ccxxiii Ellis, Ireland in the age of the Tudors, 35. Military service was emphasized in petitions to the crown, and in the many versions of Gerald of Wales that were translated and copied in the fifteenth and sixteenth centuries: Caoimhe Whelan, "Translating the Expugnatio Hibernica: transmission of a vernacular history for a late medieval English colony" in Carrie Griffin and Emer Purcell (eds.), Migration \& manipulation: texts, translation \& transmission (forthcoming). ccxiv State Papers, Henry VIII, iii, no. 3, 266-70; Emmett O’Byrne, “Toirdhealbhach Ó Tuathail” in DIB.

${ }^{\text {ccxxv }}$ Heller, "Anxiety, hierarchy, and appearance”, 333.

ccxxvi Miskimin, Money and Power, 118-9; Wilson, "Common threads", 148-9.

ccxxvii Heller, "Angevin-Sicilian sumptuary statutes", 88-9, 92-3.

ccxxviii A striking bit of evidence for the attention paid to status distinctions within colonial society is the dispute in the Irish parliament in 1460-2 between Robert Preston, lord of Gormanston, and the barons of Slane about where their appropriate seats were in parliament in terms of preeminence. Fleming was accused of absenting himself from parliament so that the issue would be delayed until the members who knew that his ancestors sat below Preston's had died.

Parliamentary pre-eminence, was, evidently, left to the communal memory of the peers: Stat. Ire., Hen VI, 710-13; Stat. Ire., Ed. IV, 1-12, 35-7. This dispute about parliamentary seats was part of a larger dispute between these competing and interrelated families of the Meath maghery: Stat. Ire., Ed. IV , 1-12, 50-5; Emmett O’Byrne, "Thomas Fleming (d.1434/5)" in DIB. 